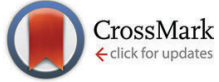

Cite this: Phys. Chem. Chem. Phys., $2015,17,5712$

Received 14th November 2014 Accepted 16th January 2015

DOI: $10.1039 / c 4 c p 05294 c$

www.rsc.org/pccp

\section{The fundamental flaw of the HSAB principle is revealed by a complete speciation analysis of the $\left[\mathrm{PtCl}_{6-n} \mathrm{Br}_{n}\right]^{2-}(n=0-6)$ system $\dagger$}

\author{
W. J. Gerber, ${ }^{*}$ P.-H. van Wyk, D. M. E. van Niekerk and K. R. Koch
}

\begin{abstract}
Bjerrum's model of step-wise ligand exchange is extended to compute a complete speciation diagram for the $\left[\mathrm{PtCl}_{6-n} \mathrm{Br}_{n}\right]^{2-}(n=0-6)$ system including all 17 equilibrium constants concerning the Pt ${ }^{\mathrm{IV}}$ chloridobromido exchange reaction network (HERN). In contrast to what the hard soft acid base (HSAB) principle "predicts", the thermodynamic driving force for the replacement of chloride by bromide in an aqueous matrix, for each individual ligand exchange reaction present in the Pt ${ }^{\mathrm{IV}} \mathrm{HERN}$, is due to the difference in halide hydration energy and not bonding interactions present in the acid-base complex. A generalized thermodynamic test calculation was developed to illustrate that the HSAB classified class (b) metal cations $\mathrm{Ag}^{+}, \mathrm{Au}^{+}, \mathrm{Au}^{3+}, \mathrm{Rh}^{3+}, \mathrm{Cd}^{2+}, \mathrm{Pt}^{2+}, \mathrm{Pt}^{4+}, \mathrm{Fe}^{3+}, \mathrm{Cd}^{2+}, \mathrm{Sn}^{2+}$ and $\mathrm{Zn}^{2+}$ all form thermodynamically stable halido complexes in the order $\mathrm{F}^{-} \gg \mathrm{Cl}^{-}>\mathrm{Br}^{-}>\mathrm{I}^{-}$irrespective of the sample matrix. The bonding interactions in the acid-base complex, e.g. ionic-covalent $\sigma$-bonding, $\Pi$-bonding and electron correlation effects, play no actual role in the classification of these metal cations using the HSAB principle. Instead, it turns out that the hydration/solvation energy of halides is the reason why metal cations are categorized into two classes using the HSAB principle which highlights the fundamental flaw of the HSAB principle.
\end{abstract}

\section{Introduction}

The most extensively studied stepwise ligand exchange equilibria across the periodic table are those concerning metal cation halido complexes. ${ }^{1,2}$ When Ahrland scrutinized the available overall formation constants $\left(\beta_{i}\right)$ of $\mathrm{p}-, \mathrm{d}$ - and f-block metal halido complexes in solution, ${ }^{2}$ he found that metal cations can be divided into two groups. In the first group, thermodynamically stable halido complexes occur in the order $\mathrm{F}^{-} \gg \mathrm{Cl}^{-}>\mathrm{Br}^{-}>\mathrm{I}^{-}$ and in the second group, a triangular 'island of stability' in the periodic table, the thermodynamic stability order is the exact opposite. This 'triangular' region mainly contains the platinum group metals (PGM) and several metal cations that border the precious metals. Subsequently, numerous investigations have echoed Arland's observations as illustrated by the statement of Preetz et al.; "The overall stability constant $\beta_{6}=36000$ indicates the greater stability of $\left[\mathrm{RhBr}_{6}\right]^{3-}$ in comparison to $\left[\mathrm{RhCl}_{6}\right]^{3-,}$, and led in part to Pearson's proposal of the hard soft acid base (HSAB) concept. ${ }^{3}$

The HSAB principle has in many respects guided the rationale w.r.t. which chemical species have a larger affinity for each

Research Group of PGM Chemistry, Department of Chemistry and Polymer Science, Stellenbosch University, Private Bag XI, Stellenbosch 7602, Western Cape, South Africa. E-mail: wgerber@sun.ac.za; Fax: +27 021808 3342; Tel: +27 0218082699 $\dagger$ Electronic supplementary information (ESI) available. See DOI: 10.1039/ c4cp05294c other over the last half century, and in this context guided synthetic approaches to prepare novel coordination compounds. However, in a recent review Mayr et al. ${ }^{4}$ convincingly demonstrates, with detailed examples, how HSAB fails in the prediction of ambident reactivity for the rational design of organic molecules. In the same review Mayr et al. states "the concept of HSAB proved to be useful for rationalizing stability constants of metal complexes". It was of interest to us why HSAB is apparently useful for inorganic/organometallic "systems" but not for organic reactions. Pearson has published approximately 25 research articles in which the HSAB concept is expanded and in some cases defended. However, at the centre of the HSAB concept is the hypothesis that there are two groups of chemical species, i.e. class (a) or hard and class (b) or soft and some 'borderline' cases not discussed in detail. The following statement by Pearson, and according to Pearson an idea not well understood by many, ${ }^{5}$ is considered to be the core rationale of the HSAB principle "Also solvation effects alone would not cause a division into two distinct classes of acids as are found. What solvation does do is to generally destroy class (a) character and enhance class (b) character. The magnitude of the class (a) character in the gas phase will determine if a solvent can cause inversion (...). It is clear then that solvation effects, while of great importance, particularly for ions, do not explain why some acids prefer hard bases and some acids prefer soft base. The explanation for this must come from interactions existing in 
the acid-base complex. Such interactions include ionic-covalent $\sigma$-bonding, $\Pi$-bonding, electron correlation effects, all of which seem to play a role in determining class (a) and (b), or hard and soft character. ${ }^{3}$ It is clear from this statement that if it can be proved that hydration/solvation is the only reason why there seems to be two distinct classes of acids (metal cations) or bases then the HSAB principle might be shown to be fundamentally flawed.

The HSAB classification of metal cations as "hard" or "soft" is primarily based on bond energies, rates of reaction, the existence or non-existence of certain compounds and the magnitude of equilibrium constants especially for metal-ligand equilibria. ${ }^{5}$ Metal-ligand equilibrium constants are calculated, ${ }^{6}$ almost exclusively, using the model of Bjerrum et al. ${ }^{7,8}$ involving stepwise ligand exchange reactions, Scheme 1a. In this model, isomerization and ligand 'cross' substitution reactions as shown in the halide exchange reaction network (HERN) in Scheme 1b are neglected. Disregard of these reactions not only results in the loss of thermodynamic information and an internal self-consistency check by which to quantitatively validate calculated ligand exchange equilibrium constants (vide infra), but also raises the question of how the equilibrium constants shown in Scheme $1 \mathrm{a}$ and $\mathrm{b}$ are mathematically related to one another. Moreover, if it is to be shown here that hydration/solvation energies are the only reason why metal cations are classified as "hard" or "soft", it is vital that a complete speciation analysis must be performed as depicted in Scheme 1b such that there can be no possibility that individual step-wise ligand exchange reactions, e.g. fac- $\left[\mathrm{PtCl}_{3} \mathrm{Br}_{3}\right]^{2-}+[\mathrm{Br}]^{-} \rightleftharpoons$ cis-[ $\left[\mathrm{PtCl}_{2} \mathrm{Br}_{4}\right]^{2-}+[\mathrm{Cl}]^{-}$, may alter our conclusions.

In this paper we extend Bjerrum's model of step-wise ligand exchange, Scheme 1a, to a complete speciation study of the $\mathrm{Pt}^{\mathrm{IV}}$ chlorido-bromido HERN, Scheme $1 \mathrm{~b}$, for the determination of all 17 equilibrium constants. The deceptively 'simple' $\left[\mathrm{PtCl}_{6-n} \mathrm{Br}_{n}\right]^{2-}$ ( $n=0-6)$ HERN is an ideal chemical system to demonstrate our conjecture that the HSAB classification of metal cations is based on hydration/solvation energies and not upon the interactions existing in the acid-base complex. This analysis will then be compared to Bjerrum's model, Scheme 1a, with an emphasis on the quantitative validation of all calculated ligand exchange stability constants. Moreover, we derive the mathematical relations between the ligand exchange equilibrium constants for the reactions shown in Scheme 1a and b to illustrate how standard reaction Gibbs free energies for certain reactions in Scheme 1a have previously been incorrectly calculated. The focus is then directed towards establishing the thermodynamic driving force for $\mathrm{Pt}^{\mathrm{IV}}$ chlorido-bromido ligand exchange reactions in solution, and also to demonstrate why the 'semi-quantitative' experimental work of Schlesinger ${ }^{10}$ led Ahrland to incorrectly conclude that the relatively high oxidation state $\mathrm{Pt}^{\mathrm{IV}}$ cation unequivocally belongs to the second group or class (b) in HSAB terminology. From the above considerations a generalized thermodynamic test calculation is developed in order to ascertain the bonding preference of all metal cations with halido ligands in solution, to ultimately evaluate the overall validity of the HSAB principle.

In a later attempt by Pearson in collaboration with Par, the HSAB principle was "theoretically" refined in an attempt to calculate an absolute hardness value using density functional theory (DFT). ${ }^{5}$ This refined HSAB model does not change however the original HSAB predictions nor its interpretation. With the use of quantum computational thermodynamic data, using DFT for several representative class (a) and (b) metal cations, it is shown that the refined chemical hardness concepts may also be of little value. Lastly, the case is made that the HSAB principle inhibits inorganic/organometallic synthetic methodology to produce novel complexes.

(a)

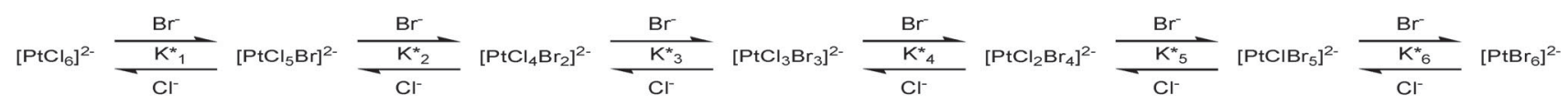

(b)

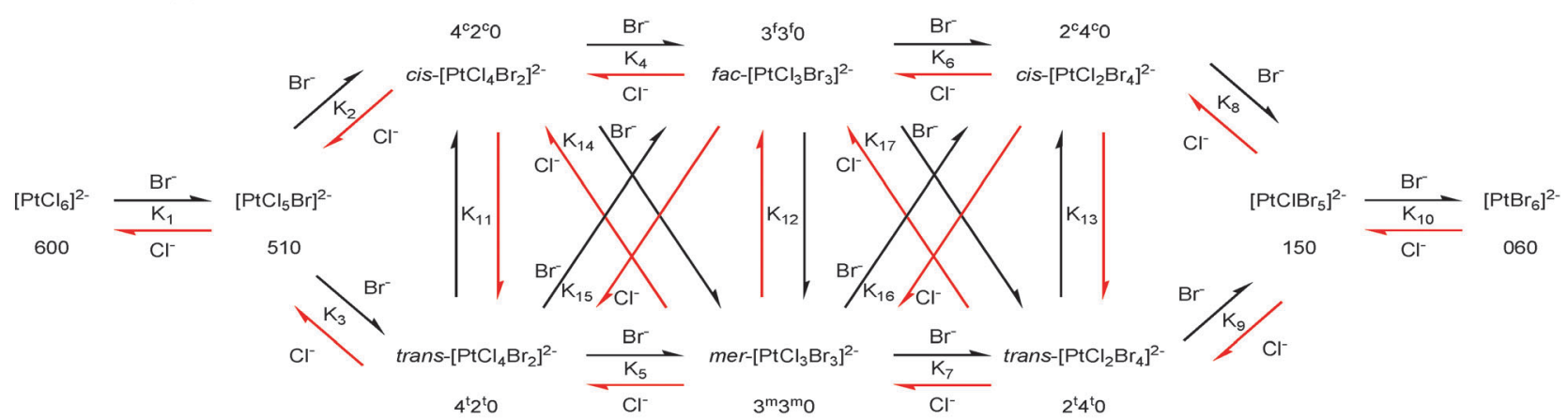

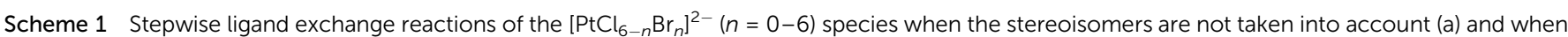

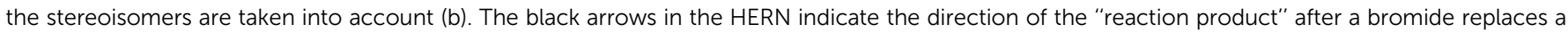

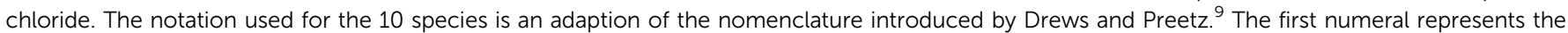

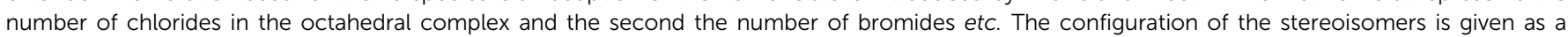
superscript; c for cis, t for trans, $m$ for meridional, and for facial. 


\section{Experimental results}

To synthesize the 10 possible $\left[\mathrm{PtCl}_{6-n} \mathrm{Br}_{n}\right]^{2-}(n=0-6)$ complex anions in a 'stepwise' manner, the bromide/chloride mole fraction $\left(\alpha_{\mathrm{Br}^{-}}=\frac{n_{\mathrm{Br}^{-}}}{n_{\mathrm{Br}^{-}}+n_{\mathrm{Cl}^{-}}}\right)$was systematically varied in a series of samples whilst keeping the total $\left[\mathrm{Pt}^{\mathrm{IV}}\right]_{\mathrm{T}}$ and halide concentration $\left([\mathrm{Cl}]^{-}+[\mathrm{Br}]^{-}\right)$constant at $10.02 \mathrm{mM}$ and $1.001 \mathrm{M}$, respectively. The $\mathrm{Pt}^{\mathrm{IV}}$ samples were stored at $294.1 \mathrm{~K}$ for approximately 8 weeks and periodically irradiated with light to accelerate ligand exchange. ${ }^{11}$ These samples were analysed to determine all $\mathrm{Pt}^{\mathrm{IV}}$ species concentration with an ion-pair-HPLC-UV-Vis technique that we previously developed. ${ }^{12}$ Injection of a sample onto the $\mathrm{C}_{18}$ reversed phase column was immediately done after a 15 fold dilution, using an aqueous acetate solution buffered at $\mathrm{pH}=4.64$, to ensure that the extent to which ligand exchange reactions take place is insignificant for these relatively kinetically stable complex anions before analysis. The UV-Vis chromatographic traces at 262 and $315 \mathrm{~nm}$ obtained are shown in Fig. 1a and b, with the unambiguous assignment of the $10 \mathrm{Pt}^{\mathrm{IV}}$ complexes. ${ }^{12}$ Baseline separation for the $\left[\mathrm{PtCl}_{6-n} \mathrm{Br}_{n}\right]^{2-}(n=0-6)$ complex anions is achieved and only a relatively small amount of peak overlap occurs for the stereoisomers $(n=2,3$ and 4). Jeansonne et al. demonstrated that accurate peak area deconvolution can be performed for these cases using an exponentially modified Gaussian equation. ${ }^{13}$

In an acidic, $\sim 1.0 \mathrm{M}$ free chloride matrix, $\mathrm{Pt}^{\mathrm{IV}}$ forms the $\left[\mathrm{PtCl}_{6}\right]^{2-}$ complex anion in over $99 \%$ abundance, Fig. 1a. As the $\alpha_{\mathrm{Br}-}$ increases the heteroleptic $\left[\mathrm{PtCl}_{6-n} \mathrm{Br}_{n}\right]^{2-}(n=2-5)$ complex anions amounts increase and decrease in a "stepwise" manner, Fig. 2, best pictorially illustrated by the $\left[\mathrm{PtClBr}_{5}\right]^{2-}$ species UV-Vis signal response, Fig. 1b. The peak associated with $\left[\mathrm{PtBr}_{6}\right]^{2-}$ is already observed at a relatively low $\alpha_{\mathrm{Br}-}$ and continues to increase in area until reaching a maximum when the $\alpha_{\mathrm{Br}^{-}}=1$ with no other $\mathrm{Pt}^{\mathrm{IV}}$ species detected.

Even though the rate of ligand exchange for these $\left[\mathrm{PtCl}_{6-n} \mathrm{Br}_{n}\right]^{2-}$ $(n=0-6)$ complex anions is relatively slow, ${ }^{14}$ it was found that after

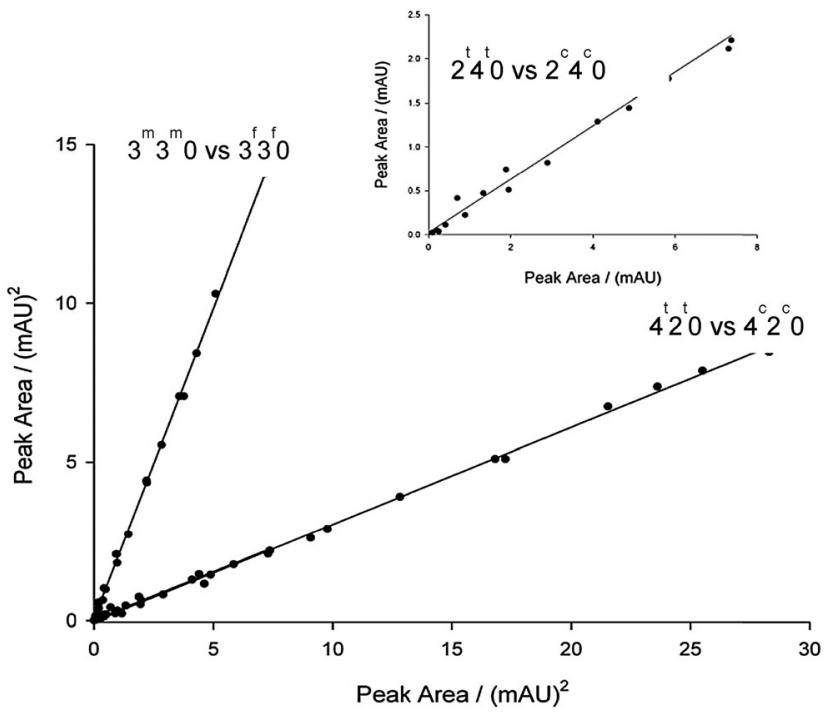

Fig. 2 Linear relationships between stereoisomer pair peak areas at $262 \mathrm{~nm}$. The relatively larger scatter of data observed in the insert figure is due to the signal to noise ratio being lower for the $2^{c} 4^{c} 0$ and $2^{t} 4^{t} 0$ stereoisomer pair peak areas.

8 weeks and subsequent periodic injection of the samples for another 3 weeks that the $\mathrm{Pt}^{\mathrm{IV}}$ complex anion UV-Vis absorbance peak areas remain constant, giving an indication that equilibrium had been attained. The attainment of equilibrium for this system was also tested quantitatively in the following manner. The ability to directly measure stereoisomer (cis/trans, fac/mer) species amounts, and the fact that there is a linear relationship between the concentration of stereoisomer pairs, e.g. eqn (1) and (2) where $\mathrm{PA}=$ peak area and $j=$ arbitrary constant relating peak area to concentration, allows for a straightforward graphical technique to confirm whether the $\mathrm{Pt}^{\mathrm{IV}}$ system is at equilibrium, i.e. graphs of stereoisomer pair peak areas will be linear, Fig. 2 , if and only if the system is at a)

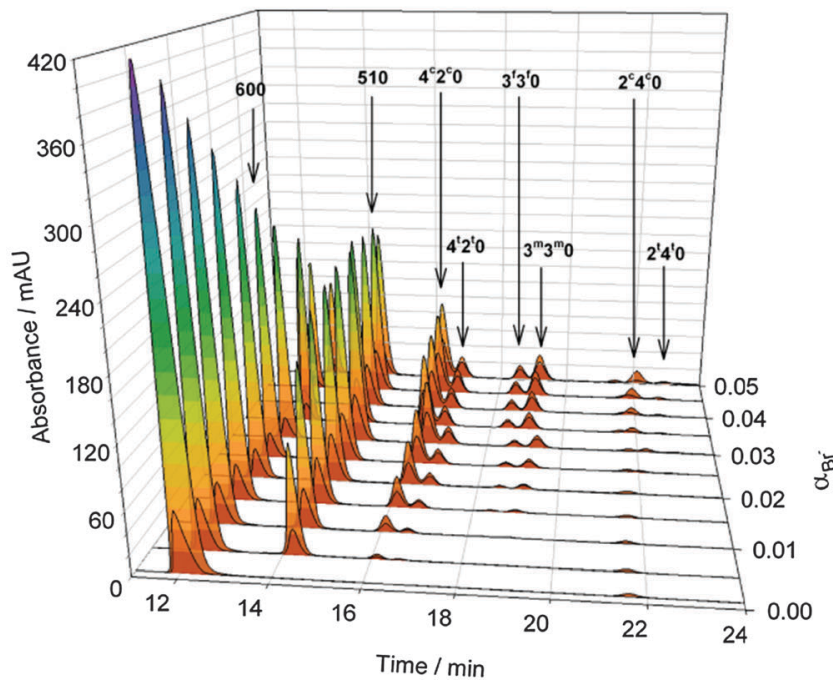

b)

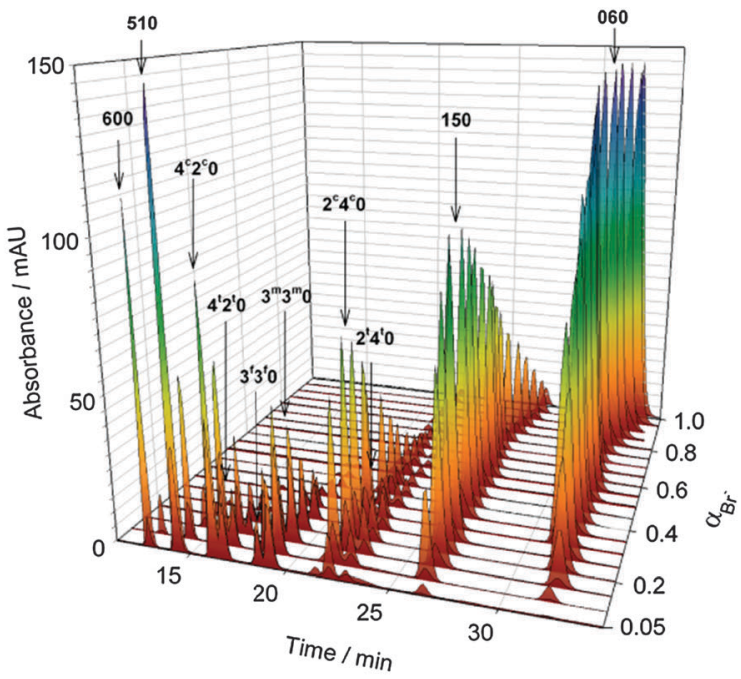

Fig. 1 Chromatographic traces depicting the stepwise manner in which $\left[\mathrm{PtCl}_{6-n} \mathrm{Br}_{n}\right]^{2-}(n=0-6)$ complex anions increase and decrease as a function of the $\mathrm{Br}^{-}$mole fraction at $294.1 \mathrm{~K}$ (a) $\mathrm{Br}^{-}$mole fraction in the range of 0 to 0.05 and (b) $\mathrm{Br}^{-}$mole fraction range of 0.05 to 1.0 . 
equilibrium at constant temperature and pressure. The reason for this condition stems from kinetic considerations of ligand exchange, e.g. the kinetic trans effect can cause a concentration build-up of only one stereoisomer due to the relatively slow rate of ligand exchange reactions that should increase the concentration of the other stereoisomer in a pair. ${ }^{15-18}$ Inspection of Fig. 2 confirms that the $\left[\mathrm{PtCl}_{6-n} \mathrm{Br}_{n}\right]^{2-}(n=0-6)$ species have attained their respective equilibrium concentrations.

$$
\begin{gathered}
K_{17}=\frac{\left[\text { trans }-\mathrm{PtBr}_{4} \mathrm{Cl}_{2}{ }^{2-}\right]}{\left[\text { cis }-\mathrm{PtBr}_{4} \mathrm{Cl}_{2}{ }^{2-}\right]}=\frac{\mathrm{PA}_{\text {trans }-}\left[\mathrm{PtBr}_{4} \mathrm{Cl}_{2}\right]^{2-} \cdot j_{\text {trans }-}\left[\mathrm{PtBr}_{4} \mathrm{Cl}_{2}\right]^{2-}}{\mathrm{PA}_{\text {cis }-}\left[\mathrm{PtBr}_{4} \mathrm{Cl}_{2}\right]^{2-} \cdot j_{\text {cis }-}\left[\mathrm{PtBr}_{4} \mathrm{Cl}_{2}\right]^{2-}} \\
\mathrm{PA}_{\text {trans }-\left[\mathrm{PtBr}_{4} \mathrm{Cl}_{2}\right]^{2-}}=K_{17} \frac{j_{\text {cis }-}\left[\mathrm{PtBr}_{4} \mathrm{Cl}_{2}\right]^{2-}}{j_{\text {trans }-}-\left[\mathrm{PtBr}_{4} \mathrm{Cl}_{2}\right]^{2-}} \mathrm{PA}_{\text {cis }-\left[\mathrm{PtBr}_{4} \mathrm{Cl}_{2}\right]^{2-}}
\end{gathered}
$$

\section{Discussion}

Extending Bjerrum's proposal of stepwise ligand exchange to a complete speciation calculation for the $\left[\operatorname{PtCl}_{6-n} \mathrm{Br}_{n}\right]^{2-}(n=0-6)$ system

The HSAB classification of metal cations as "hard" or "soft" relies in many cases on the magnitude of ligand exchange equilibrium constants or rather overall formation constants. In this context we first focus on the relationships that exist between the 6 step-wise stability constants $\left(K_{i}^{*}\right)$ defined in Scheme $1 \mathrm{a}$ and the 17 stability constants $\left(K_{i}\right)$ in Scheme $1 \mathrm{~b}$. After several algebraic steps, shown in the computational section, eqn (3)-(8) were derived expressing the step-wise stability constants $K_{i}^{*}(i=1-6)$, Scheme 1 a, as a function of $K_{i}$ ( $i=1-10)$, scheme $1 \mathrm{~b}$.

$$
\begin{gathered}
K_{1}{ }^{*}=K_{1}=\frac{\left(\left[\mathrm{PtCl}_{5} \mathrm{Br}\right]^{2-}\right)\left([\mathrm{Cl}]^{-}\right)}{\left(\left[\mathrm{PtCl}_{6}\right]^{2-}\right)[\mathrm{Br}]^{-}} \\
K_{2}{ }^{*}=K_{2}+K_{3}=\frac{\left(\left[\mathrm{PtCl}_{4} \mathrm{Br}_{2}\right]^{2-}\right)\left([\mathrm{Cl}]^{-}\right)}{\left(\left[\mathrm{PtCl}_{5} \mathrm{Br}^{2-}\right)\left([\mathrm{Br}]^{-}\right)\right.} \\
K_{3}{ }^{*}=\frac{K_{2} K_{4}}{K_{2}{ }^{*}}+\frac{K_{3} K_{5}}{K_{2}{ }^{*}}=\frac{\left(\left[\mathrm{PtCl}_{3} \mathrm{Br}_{3}\right]^{2-}\right)\left([\mathrm{Cl}]^{-}\right)}{\left(\left[\mathrm{PtCl}_{4} \mathrm{Br}_{2}\right]^{2-}\right)\left([\mathrm{Br}]^{-}\right)} \\
K_{4}^{*}=\frac{K_{2} K_{4} K_{6}}{K_{2}{ }^{*} K_{3}{ }^{*}}+\frac{K_{3} K_{5} K_{7}}{K_{2}{ }^{*} K_{3}{ }^{*}}=\frac{\left(\left[\mathrm{PtCl}_{2} \mathrm{Br}_{4}\right]^{2-}\right)\left([\mathrm{Cl}]^{-}\right)}{\left(\left[\mathrm{PtCl}_{3} \mathrm{Br}_{3}\right]^{2-}\right)\left([\mathrm{Br}]^{-}\right)} \\
K_{5}{ }^{*}=\frac{K_{2} K_{4} K_{6} K_{8}}{K_{2}{ }^{*} K_{3}{ }^{*} K_{4}{ }^{*}} \vee \frac{K_{3} K_{5} K_{7} K_{9}}{K_{2}{ }^{*} K_{3}{ }^{*} K_{4}{ }^{*}}=\frac{\left(\left[\mathrm{PtClBr}_{5}\right]^{2-}\right)\left([\mathrm{Cl}]^{-}\right)}{\left(\left[\mathrm{PtCl}_{2} \mathrm{Br}\right]^{2-}\right)\left([\mathrm{Br}]^{-}\right)} \\
K_{6}{ }^{*}=K_{10}=\frac{\left(\left[\mathrm{PtBr}_{6}\right]^{2-}\right)\left([\mathrm{Cl}]^{-}\right)}{\left(\left[\mathrm{PtClBr}_{5}\right]^{2-}\right)\left([\mathrm{Br}]^{-}\right)}
\end{gathered}
$$

Inspection of eqn (3)-(8) reveals that $K_{i}^{*}(i=2-5)$ are a combination of several $K_{i}(i=1-9)$ which in turn results in, for example, a $K_{2}{ }^{*}$ constant that is too large and a $K_{5}{ }^{*}$ constant that is too small and by implication erroneous standard reaction Gibbs free energies. This is a direct consequence resulting from the neglect of stereoisomer formation and "cross" ligand exchange equilibria in Bjerrum's formulation, scheme 1a. To evaluate the implications of these issues on the computed overall formation constants requires a complete speciation calculation using in our case all 10 of the $\left[\mathrm{PtCl}_{6-n} \mathrm{Br}_{n}\right]^{2-}$ $(n=0-6)$ complex anions. The first step in this process is to derive the respective mass-balance equations for the reaction models depicted in Scheme 1a and b. This is done by expressing the stepwise ligand exchange equilibria, scheme 1a, in terms of their respective overall formation constants, reaction (9) and eqn (10).

$$
\begin{gathered}
{\left[\mathrm{PtCl}_{6}\right]^{2-}+n \mathrm{Br}^{-} \stackrel{\beta_{n}{ }^{*}}{\rightleftharpoons}\left[\mathrm{PtCl}_{6-n} \mathrm{Br}_{n}\right]^{2-}+n \mathrm{Cl}^{-}(n=0-6)} \\
\beta_{n}{ }^{*}=\frac{\left(\left[\mathrm{PtCl}_{6-n} \mathrm{Br}_{n}\right]^{2-}\right)\left([\mathrm{Cl}]^{-}\right)^{n}}{\left(\left[\mathrm{PtCl}_{6}\right]^{2-}\right)\left([\mathrm{Br}]^{-}\right)^{n}}(n=0-6)
\end{gathered}
$$

Substitution of eqn (10) into (11) below, yields the final Pt mass-balance eqn (12) which is solved simultaneously with the analogous chloride and bromide mass-balance equations to obtain all the $\left[\mathrm{PtCl}_{6-n} \mathrm{Br}_{n}\right]^{2-}(n=0-6)$ species and unbound/free halide concentrations.

$$
\begin{aligned}
{[\mathrm{Pt}]_{\mathrm{T}}=} & {\left[\mathrm{PtCl}_{6}\right]^{2-}+\left[\mathrm{PtCl}_{5} \mathrm{Br}\right]^{2-}+\left[\mathrm{PtCl}_{4} \mathrm{Br}_{2}\right]^{2-}+\left[\mathrm{PtCl}_{3} \mathrm{Br}_{3}\right]^{2-} } \\
& +\left[\mathrm{PtCl}_{2} \mathrm{Br}_{4}\right]^{2-}+\left[\mathrm{PtClBr}_{5}\right]^{2-}+\left[\mathrm{PtBr}_{6}\right]^{2-} \\
{[\mathrm{Pt}]_{\mathrm{T}}=} & \left.\left(\left[\mathrm{PtCl}_{6}\right]^{2-}\right)+\beta_{1}{ }^{*}\left([\mathrm{PtCl}]_{6}\right]^{2-}\right) \frac{\left([\mathrm{Br}]^{-}\right)}{\left([\mathrm{Cl}]^{-}\right)} \\
& +\beta_{2}{ }^{*}\left(\left[\mathrm{PtCl}_{6}\right]^{2-}\right) \frac{\left([\mathrm{Br}]^{-}\right)^{2}}{\left([\mathrm{Cl}]^{-}\right)^{2}}+\beta_{3}^{*}\left(\left[\mathrm{PtCl}_{6}\right]^{2-}\right) \frac{\left([\mathrm{Br}]^{-}\right)^{3}}{\left([\mathrm{Cl}]^{-}\right)^{3}} \\
& +\beta_{4}{ }^{*}\left(\left[\mathrm{PtCl}_{6}\right]^{2-}\right) \frac{\left([\mathrm{Br}]^{-}\right)^{4}}{\left([\mathrm{Cl}]^{-}\right)^{4}}+\beta_{5}{ }^{*}\left(\left[\mathrm{PtCl}_{6}\right]^{2-}\right) \frac{\left([\mathrm{Br}]^{-}\right)^{5}}{\left([\mathrm{Cl}]^{-}\right)^{5}} \\
& +\beta_{6}{ }^{*}\left(\left[\mathrm{PtCl}_{6}\right]^{2-}\right) \frac{\left([\mathrm{Br}]^{-}\right)^{6}}{\left([\mathrm{Cl}]^{-}\right)^{6}}
\end{aligned}
$$

Using the same procedure as above, but for the reaction scheme shown in Scheme $1 \mathrm{~b}$, i.e. using the "overall" reaction(s) 13, with the substitution of eqn (14) into eqn (15), the equivalent final Pt mass-balance eqn (16) is obtained.

$$
\begin{gathered}
{\left[\mathrm{PtCl}_{6}\right]^{2-}+x \mathrm{Br}^{-} \stackrel{\beta_{n}}{\rightleftharpoons}\left[\mathrm{PtCl}_{6-x} \mathrm{Br}_{x}\right]^{2-}+x \mathrm{Cl}^{-}} \\
(n=1-10, x=1-6) \\
\beta_{n}=\frac{\left(\left[\mathrm{PtCl}_{6-x} \mathrm{Br}_{x}\right]^{2-}\right)\left([\mathrm{Cl}]^{-}\right)^{x}}{\left(\left[\mathrm{PtCl}_{6}\right]^{2-}\right)\left([\mathrm{Br}]^{-}\right)^{x}}(n=1-10, x=1-6)
\end{gathered}
$$

$$
\begin{aligned}
{[\mathrm{Pt}]_{\mathrm{T}}=} & {\left[\mathrm{PtCl}_{6}\right]^{2-}+\left[\mathrm{PtCl}_{5} \mathrm{Br}\right]^{2-}+\left[c-\mathrm{PtCl}_{4} \mathrm{Br}_{2}\right]^{2-}+\left[t-\mathrm{PtCl}_{4} \mathrm{Br}_{2}\right]^{2-} } \\
& +\left[f-\mathrm{PtCl}_{3} \mathrm{Br}_{3}\right]^{2-}+\left[m-\mathrm{PtCl}_{3} \mathrm{Br}_{3}\right]^{2-}+\left[c-\mathrm{PtCl}_{2} \mathrm{Br}_{4}\right]^{2-} \\
& +\left[t-\mathrm{PtCl}_{2} \mathrm{Br}_{4}\right]^{2-}+\left[\mathrm{PtClBr}_{5}\right]^{2-}+\left[\mathrm{PtBr}_{6}\right]^{2-}
\end{aligned}
$$




$$
\begin{aligned}
{[\mathrm{Pt}]_{\mathrm{T}}=} & \left(\left[\mathrm{PtCl}_{6}\right]^{2-}\right)+\beta_{1}\left(\left[\mathrm{PtCl}_{6}\right]^{2-}\right) \frac{\left([\mathrm{Br}]^{-}\right)}{\left([\mathrm{Cl}]^{-}\right)} \\
& +\left(\beta_{2}+\beta_{3}\right)\left(\left[\mathrm{PtCl}_{6}\right]^{2-}\right) \frac{\left([\mathrm{Br}]^{-}\right)^{2}}{\left([\mathrm{Cl}]^{-}\right)^{2}} \\
& +\left(\beta_{4}+\beta_{5}\right)\left(\left[\mathrm{PtCl}_{6}\right]^{2-}\right) \frac{\left([\mathrm{Br}]^{-}\right)^{3}}{\left([\mathrm{Cl}]^{-}\right)^{3}} \\
& +\left(\beta_{6}+\beta_{7}\right)\left(\left[\mathrm{PtCl}_{6}\right]^{2-}\right) \frac{\left([\mathrm{Br}]^{-}\right)^{4}}{\left([\mathrm{Cl}]^{-}\right)^{4}} \\
& +\left(\beta_{8} \vee \beta_{9}\right)\left(\left[\mathrm{PtCl}_{6}\right]^{2-}\right) \frac{\left([\mathrm{Br}]^{-}\right)^{5}}{\left([\mathrm{Cl}]^{-}\right)^{5}} \\
& +\beta_{10}\left(\left[\mathrm{PtCl}_{6}\right]^{2-}\right) \frac{\left([\mathrm{Br}]^{-}\right)^{6}}{\left([\mathrm{Cl}]^{-}\right)^{6}}
\end{aligned}
$$

Upon comparison of eqn (12) and (16) it can be seen that several of the overall formation constants $\beta_{i}^{*}(i=2-4)$ in Bjerrum's formulation, eqn (12), are actually the sum of two overall formation constants $\left(\beta_{i}\right)$ in eqn (16), for example we find that $\beta_{2}{ }^{*}=K_{1}{ }^{*} K_{2}{ }^{*}=K_{1} K_{2}+K_{1} K_{3}=\beta_{2}+\beta_{3}$. Moreover, the term that yields the concentration of $\left[\mathrm{PtClBr}_{5}\right]^{2-}$ in eqn (16) can either contain the overall formation constant $\beta_{8}$ or $\beta_{9}$, where $\beta_{8}=K_{1} K_{2} K_{4} K_{6} K_{8}$ and $\beta_{9}=K_{1} K_{3} K_{5} K_{7} K_{9}$, and since reaction Gibbs energy is a state function $\beta_{8}=\beta_{9}$. Furthermore, due to cancellation of terms when evaluating $\beta_{5}{ }^{*}$, it is found that $\beta_{5}{ }^{*}=$ $K_{1}{ }^{*} K_{2}{ }^{*} K_{3}{ }^{*} K_{4}{ }^{*} K_{5}{ }^{*}=\beta_{8}=\beta_{9}$. In summary, $\beta_{i}^{*}$ for $i=2-4$ and their associated standard reaction Gibbs free energies, are inflated in calculations due to using two reaction paths instead of one to compute the Gibbs free energy state function quantity.

To illustrate the above insight more clearly, the program EquiState.exe was used to simulate the HERN model depicted in Scheme $1 \mathrm{~b}$ and to perform the non-linear least-squares fits on the experimentally collected $\mathrm{Pt}^{\mathrm{IV}}$ mole fraction data shown in Fig. 1. This numerical analysis yields all the species molar extinction coefficients $\left(\varepsilon_{i}\right)$ as well as all $\beta_{i}$. Since the ionic strength for all $\mathrm{Pt}^{\mathrm{IV}}$ samples is identical, and considering that the $\left[\mathrm{PtCl}_{6-n} \mathrm{Br}_{n}\right]^{2-}(n=0-6)$ complexes have the same charge and presumably similar volume it is reasonable to assume that the activity coefficients of all $10 \mathrm{Pt}^{\mathrm{IV}}$ anionic complexes are identical. The same assumption was made for the halide ions in solution and we therefore used species concentrations instead of species activity, when calculating ligand exchange stability constants or $\Delta G_{\mathrm{rxn}}^{0}$ 's. The non-linear least-squares fits are shown in Fig. 3 while the calculated $\varepsilon_{n}$ 's and $K_{i}(i=1-17)$ are listed in Tables 1 and 2 respectively. The excellent non-linear least-squares fit obtained between the experimentally found $\mathrm{Pt}^{\mathrm{IV}}$ species UV-Vis peak areas and those calculated and the good agreement of $\varepsilon$ 's for the homoleptic species, ${ }^{12}$ Table 2, validate the complete model, Scheme $1 \mathrm{~b}$. It should be noted that as discussed in the computational section below the 7 stability constants $K_{i}(i=11-17)$ pertaining to isomerisation and 'cross' ligand exchange reactions are numerically 'fixed' if $K_{i}(i=2-9)$ are known.

The accuracy of calculated equilibrium constants and associated standard reaction Gibbs energies can now be further

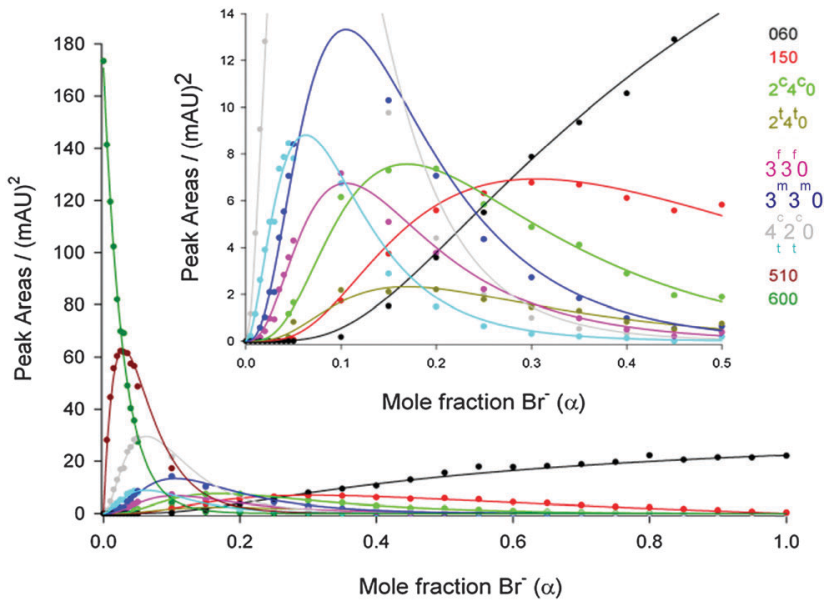

Fig. 3 Non-linear least-squares fit between the experimentally found (at $262 \mathrm{~nm}$ ) and calculated $\left[\mathrm{PtCl}_{6-n} \mathrm{Br}_{n}\right]^{2-}(n=0-6)$ species distribution. Lines $=$ simulated curves and Symbols $=$ experimental data.

scrutinized using the fact that Gibbs energy is a state function. There are multiple paths by which one $\mathrm{Pt}^{\mathrm{IV}}$ chlorido bromido complex can be converted into another, e.g. $\left[\mathrm{PtCl}_{5} \mathrm{Br}\right]^{2-}$ can be converted to $\left[\mathrm{PtClBr}_{5}\right]^{2-}$ by the following two reaction paths; path 1, $\left[\mathrm{PtCl}_{5} \mathrm{Br}\right]^{2-} \rightarrow$ cis- $\left[\mathrm{PtCl}_{4} \mathrm{Br}_{2}\right]^{2-} \rightarrow$ fac $-\left[\mathrm{PtCl}_{3} \mathrm{Br}_{3}\right]^{2-} \rightarrow$ cis$\left[\mathrm{PtCl}_{2} \mathrm{Br}_{4}\right]^{2-} \rightarrow\left[\mathrm{PtClBr}_{5}\right]^{2-}$ and path 2, $\left[\mathrm{PtCl}_{5} \mathrm{Br}\right]^{2-} \rightarrow$ trans$\left[\mathrm{PtCl}_{4} \mathrm{Br}_{2}\right]^{2-} \rightarrow$ mer $-\left[\mathrm{PtCl}_{3} \mathrm{Br}_{3}\right]^{2-} \rightarrow$ trans $-\left[\mathrm{PtCl}_{2} \mathrm{Br}_{4}\right]^{2-} \rightarrow$ $\left[\mathrm{PtClBr}_{5}\right]^{2-}$. The overall changes in standard reaction Gibbs energy for the two reaction paths are equal, yielding the energy conservation relationship eqn (17). Several energy conservation equations (ECE's) can be derived for this system, of which eqn (17) is one example for an 8 member inorganic reaction 'loop'. It should be pointed out that whilst calculating the various $\beta_{i}$, using the program EquiState, no ECEs were used. ECEs only served to validate the accuracy of calculated $\Delta G_{\mathrm{rxn}}^{0}$ 's. It is therefore decidedly satisfying that upon substitution of the experimentally obtained $\Delta G_{\mathrm{rxn}, i}^{0}(i=2-9)$ into the ECE 17, a value of $0.34 \mathrm{~kJ} \mathrm{~mol}^{-1}$ was obtained which boasts well for the accuracy of calculated stability constants $K_{i}(i=2-9)$ listed in Table 2.

$$
\begin{aligned}
& \Delta G_{\mathrm{rxn}, 3}^{0}+\Delta G_{\mathrm{rxn}, 5}^{0}+\Delta G_{\mathrm{rxn}, 7}^{0}+\Delta G_{\mathrm{rxn}, 9}^{0} \\
& \quad-\left(\Delta G_{\mathrm{rxn}, 2}^{0}+\Delta G_{\mathrm{rxn}, 4}^{0}+\Delta G_{\mathrm{rxn}, 6}^{0}+\Delta G_{\mathrm{rxn}, 8}^{0}\right)=0
\end{aligned}
$$

Moreover, to further validate calculated thermodynamic parameters it is noted that the $\Delta G_{\operatorname{rxn}\left(\beta_{10}\right)}^{0}$ for reaction 18 can also be calculated using standard half-cell reduction potential $\left(E^{0}\right)$ data pertaining to the reduction of $\left[\mathrm{PtCl}_{6}\right]^{2-}$ and $\left[\mathrm{PtBr}_{6}\right]^{2-}$ to metallic Pt, relations (19) and (20). Combination of the two half-cell reactions yields reaction 18, from which eqn (21) is derived. The $\Delta G_{\operatorname{rxn}\left(\beta_{10}\right)}^{0}$ obtained in this manner is equal to $-33.6 \mathrm{~kJ} \mathrm{~mol}^{-1}$.

$$
\begin{gathered}
{\left[\mathrm{PtCl}_{6}\right]^{2-}+6 \mathrm{Br}^{-} \rightleftharpoons\left[\mathrm{PtBr}_{6}\right]^{2-}+6 \mathrm{Cl}^{-}} \\
{\left[\mathrm{PtCl}_{6}\right]_{(\mathrm{aq})}^{2-}+4 \mathrm{e}^{-} \rightleftharpoons \mathrm{Pt}(\mathrm{s})+6 \mathrm{Cl}_{(\mathrm{aq})}^{-1} \quad E_{1}^{0}=0.744 \mathrm{~V}}
\end{gathered}
$$


Table 1 Calculated molar extinction coefficients, $\varepsilon$, for the $\left[\mathrm{PtCl}_{6-n} \mathrm{Br}_{n}\right]^{2-}(n=0-6)$ complex anions at $262 \mathrm{~nm}$

\begin{tabular}{|c|c|c|c|c|c|c|c|c|c|c|}
\hline Species & 600 & 510 & $4^{c} 2^{c} 0$ & $4^{t} 2^{t} 0$ & $3^{f_{3} f_{0}}$ & $3^{m} 3^{m} 0$ & $2^{c} 4^{c} 0$ & $2^{t} 4^{t} 0$ & 150 & 060 \\
\hline
\end{tabular}

Table 2 Stability constants $K_{i}(i=0-17)$ and standard reaction Gibbs free energy $\Delta G_{\mathrm{rxn}}^{0}(i=0-17)$ for the $\left[\mathrm{PtCl}_{6-n} \mathrm{Br}_{n}\right]^{2-}(n=0-6)$ complex anions at $294.1 \mathrm{~K}$

\begin{tabular}{llrr}
\hline & $I$ & \multicolumn{1}{c}{$K_{i}$} & \multicolumn{1}{c}{$\Delta G_{\mathrm{rxn}}^{0} / \mathrm{kJ} \mathrm{mol}^{-1}$} \\
\hline Stepwise ligand substitution & 1 & $36.34 \pm 0.73$ & $-8.79 \pm 0.17$ \\
reactions & 2 & $12.46 \pm 0.25$ & $-6.17 \pm 0.12$ \\
& 3 & $4.78 \pm 0.09$ & $-3.83 \pm 0.08$ \\
& 4 & $5.30 \pm 0.11$ & $-4.08 \pm 0.08$ \\
& 5 & $25.30 \pm 0.49$ & $-7.90 \pm 0.16$ \\
& 6 & $13.93 \pm 0.28$ & $-6.44 \pm 0.13$ \\
& 7 & $2.71 \pm 0.05$ & $-2.44 \pm 0.05$ \\
& 8 & $6.54 \pm 0.13$ & $-4.59 \pm 0.09$ \\
& 9 & $18.11 \pm 0.38$ & $-7.08 \pm 0.14$ \\
Isomerisation reactions & 10 & $2.16 \pm 0.04$ & $-1.88 \pm 0.04$ \\
& 11 & $2.61 \pm 0.05$ & $-2.35 \pm 0.05$ \\
& 12 & $1.76 \pm 0.03$ & $-1.38 \pm 0.03$ \\
'Cross' ligand substitution & 13 & $2.92 \pm 0.06$ & $-2.62 \pm 0.05$ \\
reactions & 14 & $9.34 \pm 0.19$ & $-5.46 \pm 0.04$ \\
& 15 & $14.38 \pm 0.24$ & $-6.52 \pm 0.15$ \\
& 16 & $7.92 \pm 0.12$ & $-5.06 \pm 0.11$ \\
& 17 & $4.77 \pm 0.11$ & $-3.82 \pm 0.08$
\end{tabular}

$$
\begin{gathered}
{\left[\mathrm{PtBr}_{6}\right]_{(\mathrm{aq})}^{2-}+4 \mathrm{e}^{-} \rightleftharpoons \mathrm{Pt}(\mathrm{s})+6 \mathrm{Br}_{(\mathrm{aq})}^{-1} \quad E_{2}^{0}=0.657 \mathrm{~V}} \\
\Delta G_{\mathrm{rxn}\left(\beta_{10}\right)}^{0}=n \mathrm{FE}_{2}^{0}-n \mathrm{FE}_{1}^{0}=-33.6 \mathrm{~kJ} \mathrm{~mol}^{-1}
\end{gathered}
$$

The good least-squares non-linear fits obtained illustrated in Fig. 3 coupled with the exceptional agreement of the $\Delta G_{\operatorname{rxn}\left(\beta_{10}\right)}^{0} \mathrm{~s}$ values $\left(-31.94\right.$ and $\left.-33.6 \mathrm{~kJ} \mathrm{~mol}^{-1}\right)$ with two independent methods (IP-HPLC-UV-vis and electrochemically) and taking into consideration the result obtained with the ECE, eqn (17), convincingly demonstrate the accuracy of our calculated thermodynamic parameters for this system. In light of the above results, the assumption concerning the use of species concentrations and not species activity for equilibrium constant calculations are well justified.

A complete species distribution diagram for the $\left[\mathrm{PtCl}_{6-n} \mathrm{Br}_{n}\right]^{2-}$ $(n=0-6)$ system is shown in Fig. 4a, accompanied by an enlargement of the stereoisomer distributions, Fig. $4 \mathrm{~b}$.

Using eqn (3)-(8) it is possible to calculate the overall ligand exchange formation constants $\left(\beta_{i}^{*}\right)$ as proposed by Bjerrum and contrast the values obtained with the complete speciation calculation $\left(\beta_{i}\right)$ as shown in Table 3 . As expected from the above analysis the $\beta_{i}^{*}(i=2-4)$ are the sum of the corresponding $\beta_{i}$ obtained from the full speciation calculation. It is clear that the neglect of stereoisomers leads to an inflated set of $\beta_{i}^{*}(i=2-4)$ values, resulting in relatively large $\Delta G_{\mathrm{rxn}(i)}^{0}$ 's errors for the associated reactions. The impact of these errors varies from one application to the next and should be evaluated accordingly.

Considering the relative error in calculated stability and related overall formation constants for metal-ligand equilibria when Bjerrum's model is used it is of significance to examine whether DFT and/or WFT quantum computational methodologies yield chemically accurate stereoisomer distributions. The computational data for the three isomerisation reactions are summarized in Table 4. Except for functional mO6 all DFT functionals used as well as MP2 correctly predict, in vacuo, which of the stereoisomers are thermodynamically more stable, cis $>$ trans in both cases and mer $>$ fac, with errors of more than $2 \mathrm{~kJ} \mathrm{~mol}^{-1}$ compared to the experimental values. The good chemical accuracy is most likely due to some fortuitous error cancellation. $^{19-21}$ The stereoisomer distributions obtained when a cosmo or scrf solvent model is included results in a reversal of the thermodynamic stability order for some stereoisomer pairs, especially the mer and fac. Deconvolution of overall formation constants obtained using Bjerrum's model
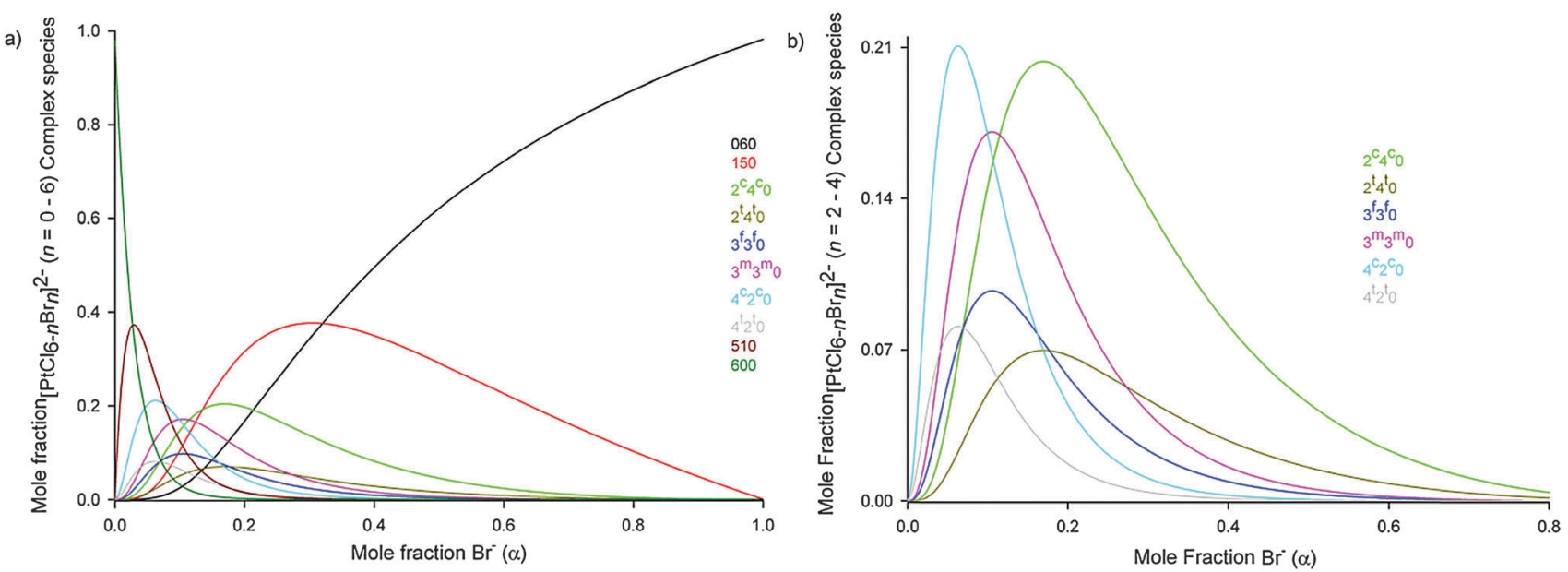

Fig. 4 (a) The complete $\left[\mathrm{PtCl}_{6-n} \mathrm{Br}_{n}\right]^{2-}(n=0-6)$ species distribution diagram and (b) zoomed in on the 3 stereoisomer pairs. 
Table 3 Comparison of the overall formation constants obtained using Bjerrum's proposal and a complete speciation calculation for the $\left[\mathrm{PtCl}_{6-n} \mathrm{Br}_{n}\right]^{2-}$ ( $n=0-6)$ complex anions at $294.1 \mathrm{~K}$

\begin{tabular}{cll}
\hline \multicolumn{3}{l}{ Overall formation constant } \\
\hline Full speciation $^{a}$ & $\beta_{1}$ & $3.63 \times 10^{1} \pm 0.73$ \\
& $\beta_{2}$ & $1.74 \times 10^{2} \pm 1.29 \times 10^{1}$ \\
$\beta_{3}$ & $4.53 \times 10^{2} \pm 4.78$ \\
$\beta_{4}$ & $4.22 \times 10^{3} \pm 8.44 \times 10^{1}$ \\
$\beta_{5}$ & $2.40 \times 10^{3} \pm 1.47 \times 10^{2}$ \\
$\beta_{6}$ & $1.14 \times 10^{4} \pm 1.35 \times 10^{3}$ \\
$\beta_{7}$ & $3.34 \times 10^{4} \pm 4.57 \times 10^{2}$ \\
$\beta_{8}$ & $2.19 \times 10^{5} \pm 9.86 \times 10^{3}$ \\
$\beta_{9}$ & $2.19 \times 10^{5} \pm 9.43 \times 10^{3}$ \\
$\beta_{10}$ & $4.72 \times 10^{5} \pm 2.21 \times 10^{4}$ \\
Partial speciation $^{b} \beta_{1}{ }^{*}=\beta_{1}$ & \\
$\beta_{2}{ }^{*}=\beta_{2}+\beta_{3}$ & $3.63 \times 10^{1} \pm 0.73$ \\
$\beta_{3}{ }^{*}=\beta_{4}+\beta_{5}$ & $6.27 \times 10^{2} \pm 1.37 \times 10^{1}$ \\
$\beta_{4}{ }^{*}=\beta_{6}+\beta_{7}$ & $6.63 \times 10^{3} \pm 1.70 \times 10^{2}$ \\
$\beta_{5}{ }^{*}=\beta_{8} \vee \beta_{9}$ & $4.49 \times 10^{4} \pm 1.42 \times 10^{3}$ \\
$\beta_{6}{ }^{*}=\beta_{10}$ & $2.19 \times 10^{5} \pm 9.86 \times 10^{3}$ \\
${ }^{a}$ Refer to Scheme $1 \mathrm{~b} .{ }^{b}$ Refer to Scheme 1a. & $4.72 \times 10^{5} \pm 2.21 \times 10^{4}$ \\
\hline
\end{tabular}

is thus possible, at least for halido complexes using the quantum computation thermodynamic data.

\section{The thermodynamic "driving force" of stepwise ligand exchange for metal cation halido complexes in aqueous solution}

From the relatively large overall formation constant, $\beta_{10}=$ $4.72 \times 10^{5}$, or from a visual inspection of the data in Fig. $4 \mathrm{a}$, it seems justified to draw the same conclusion as done in several related studies, ${ }^{1,2,5,10}$ that the thermodynamic stability of the $\mathrm{Pt}^{\mathrm{IV}}$ complexes containing bromido ligands is greater compared to the corresponding chlorido analogues, hence suggesting the HSAB classification of $\mathrm{Pt}^{\mathrm{IV}}$ as a "soft" or class (b) ion. However, for a ligand exchange reaction, e.g. the first exchange of a chloride by bromide for the $\left[\mathrm{PtCl}_{6}\right]^{2-}$ complex (eqn (22)-(25)) the halides' contribution, $\Delta \Delta G_{\mathrm{f}(\text { halide })}^{0}$, to $\Delta G_{\mathrm{rxn}\left(K_{1}\right)}^{0}$ must also be taken into consideration before a conclusion can be made concerning the relative thermodynamic stability of these complexes.

$$
\begin{gathered}
{\left[\mathrm{PtCl}_{6}\right]^{2-}+\mathrm{Br}^{-} \rightleftharpoons\left[\mathrm{PtCl}_{5} \mathrm{Br}\right]^{2-}+\mathrm{Cl}} \\
\Delta G_{\mathrm{rxn}}^{0}=\sum \Delta G_{\mathrm{f}(\text { products })}^{0}-\sum \Delta G_{\mathrm{f}(\text { reactants })}^{0} \\
\Delta G_{\mathrm{rxn} K_{1}}^{0}=\left\{\Delta G_{\mathrm{f}}^{0}\left(\left[\mathrm{PtCl}_{5} \mathrm{Br}\right]^{2-}\right)-\Delta G_{\mathrm{f}}^{0}\left(\left[\mathrm{PtCl}_{6}\right]^{2-}\right)\right\} \\
+\left\{\Delta G_{\mathrm{f}}^{0}\left([\mathrm{Cl}]^{-}\right)-\Delta G_{\mathrm{f}}^{0}\left([\mathrm{Br}]^{-}\right)\right\} \\
\Delta G_{\mathrm{rxn} K_{1}}^{0}=\Delta \Delta G_{\mathrm{f}(\text { complex })}^{0}+\Delta \Delta G_{\mathrm{f}(\text { halide })}^{0}
\end{gathered}
$$

From tabulated thermodynamic data ${ }^{22}$ the $\Delta \Delta G_{\mathrm{f}(\text { halide) }}^{0}$ term is equal to $-27.2 \mathrm{~kJ} \mathrm{~mol}^{-1}$ while the $\Delta G_{\mathrm{rxn} K_{1}}^{0}$ determined experimentally is $-8.7 \mathrm{~kJ} \mathrm{~mol}^{-1}$. Substituting these values into eqn (25) yields a value for $\Delta \Delta G_{\mathrm{f}(\text { complex) }}^{0}$ of $18.9 \mathrm{~kJ} \mathrm{~mol}^{-1}$. Moreover, for each subsequent stepwise ligand replacement reaction for the HERN the $\Delta \Delta G_{\mathrm{f}(\text { complex) }}^{0}$ term remains positive and varies only to a relatively small extent, Fig. 5 . We infer from the positive values for $\Delta \Delta G_{\mathrm{f}(\text { complex }}^{0}$ in Fig. 5 that the $\mathrm{Pt}^{\mathrm{IV}}$ chlorido complexes must be thermodynamically favoured above the corresponding bromido analogues. Furthermore, the positive $\Delta \Delta G_{\mathrm{f}(\text { complex })}^{0}$ values and the overall negative value of $\Delta G_{\mathrm{rxn}(i)}^{0}(i=1-10)$ imply that the replacement of chloride by a bromide ion is thermodynamically driven by $\Delta \Delta G_{\mathrm{f}(\text { halide) }}^{0}$ contribution, i.e. the hydration Gibbs free energy difference between bromide and chloride anions. Using the generalized gradient approximation PBE functional the $\Delta \Delta G_{\mathrm{f}(\text { (complex })}^{0}$ values were calculated in vacuo and in a simulated aqueous phase (COSMO) for successive exchange of chloride by a bromide ligand. These calculated $\Delta \Delta G_{\mathrm{f}(\text { complex })}^{0}$ values shown in Fig. 5 are in good agreement with the experimental data. Moreover, for each subsequent stepwise ligand replacement reaction the DFT calculated $\Delta \Delta G_{\mathrm{f}(\text { complex) }}^{0}$ term varies only to a small extent, in good agreement with experimental values. Inclusion of the COSMO model further favours the $\mathrm{Pt}^{\mathrm{IV}}$ chlorido complexes thermodynamically, relative to the corresponding bromido analogues. This is reasonable

Table 4 Quantum computation thermodynamic data and experimentally determined $\Delta G_{\mathrm{rxn}}^{0}$ values $\left(\mathrm{kJ} \mathrm{mol}^{-1}\right.$ ) for the 3 isomerization reactions of $\left[\mathrm{PtCl}_{n} \mathrm{Br}_{n-6}\right]^{2-}(n=2-4)$

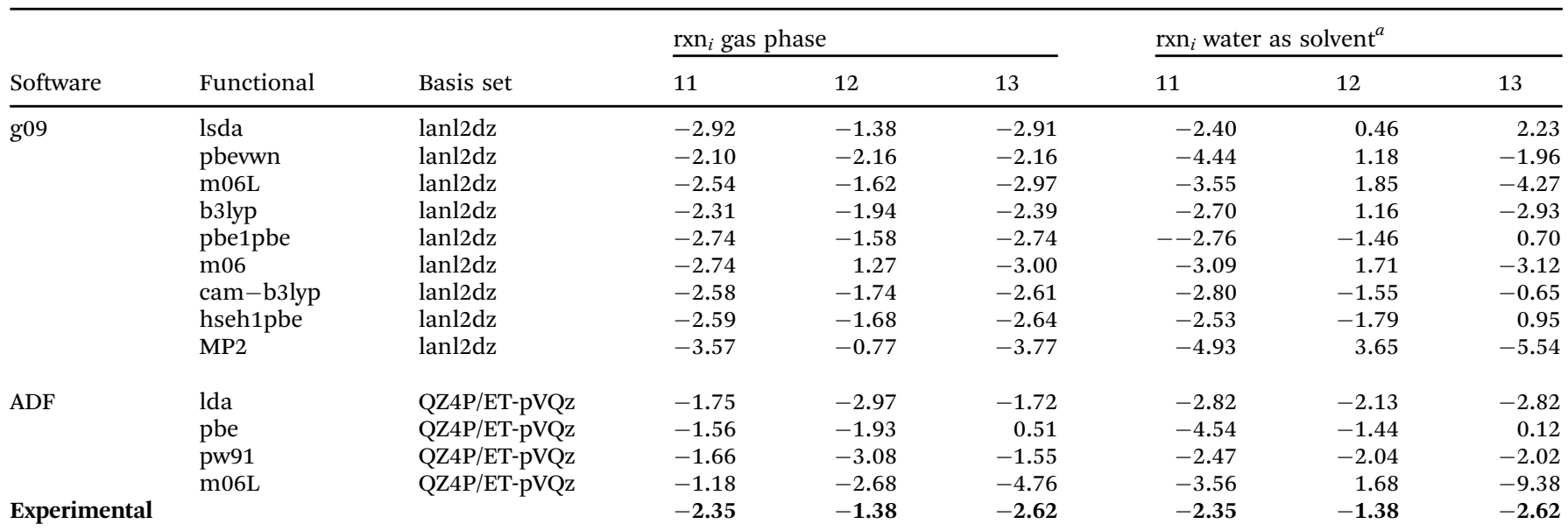

${ }^{a}$ scrf used in g09, COSMO used in ADF. 


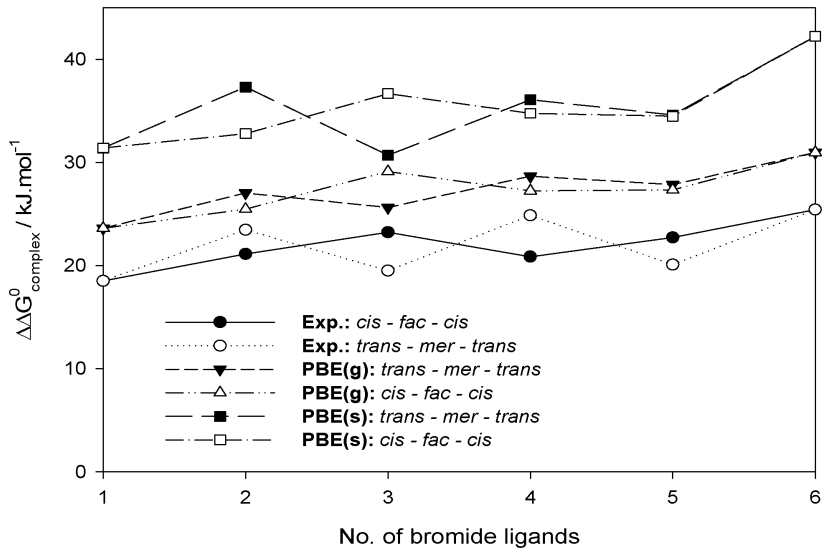

Fig. 5 Experimental and DFT calculated $\Delta \Delta G_{\mathrm{f}(\text { complex) }}^{0}$ values for successive replacement of a chloride by bromide. The two reaction paths used for these calculations are; path 1, $\left[\mathrm{PtCl}_{6}\right]^{2-} \rightarrow\left[\mathrm{PtCl}_{5} \mathrm{Br}\right]^{2-} \rightarrow$ cis- $\left[\mathrm{PtCl}_{4} \mathrm{Br}_{2}\right]^{2-} \rightarrow$ $\mathrm{fac}-\left[\mathrm{PtCl}_{3} \mathrm{Br}_{3}\right]^{2-} \rightarrow \mathrm{cis}-\left[\mathrm{PtCl}_{2} \mathrm{Br}_{4}\right]^{2-} \rightarrow\left[\mathrm{PtClBr}_{5}\right]^{2-} \rightarrow\left[\mathrm{PtBr}_{6}\right]^{2-}$ and path 2, $\left[\mathrm{PtCl}_{6}\right]^{2-} \rightarrow\left[\mathrm{PtCl}_{5} \mathrm{Br}\right]^{2-} \rightarrow$ trans- $\left[\mathrm{PtCl}_{4} \mathrm{Br}_{2}\right]^{2-} \rightarrow$ mer- $\left[\mathrm{PtCl}_{3} \mathrm{Br}_{3}\right]^{2-} \rightarrow$ trans$\left[\mathrm{PtCl}_{2} \mathrm{Br}_{4}\right]^{2-} \rightarrow\left[\mathrm{PtClBr}_{5}\right]^{2-} \rightarrow\left[\mathrm{PtBr}_{6}\right]^{2-}$.

considering the higher charge density (charge/volume) of the $\mathrm{Pt}^{\mathrm{IV}}$ chlorido species, resulting in somewhat higher hydration energies.

The experimental and DFT computational results leads to the same conclusion that $\mathrm{Pt}^{\mathrm{IV}}$ forms thermodynamically more stable chlorido complexes compared to the corresponding bromido analogues. Accordingly $\mathrm{Pt}^{\mathrm{IV}}$ should better be classified as a class (a) metal cation in contradiction to Ahrland ${ }^{2}$ who concluded, based on the 'semi-quantitative' experimental work of Schlesinger,${ }^{10}$ that the relatively high oxidation state of $\mathrm{Pt}^{\mathrm{IV}}$ cation unequivocally belongs to the second group of metal cations or class (b) in HSAB terminology.

Further experimental evidence of this assertion is found from the work of Preetz et al. ${ }^{1,23}$ reporting that several class (b) metal cation fluorido complexes are readily prepared in nonpolar solvents by means of phase transfer of $\mathrm{F}^{-}$by long-chain alkyl ammonium cations ([$\left[\mathrm{NR}_{4}\right]^{+}$where $\mathrm{R}=$ alkyl chain). This observation is readily explained when it is taken into account that the $\Delta \Delta G_{\text {f(halide) }}^{0}$ contribution towards $\Delta G_{\mathrm{rxn}}^{0}$ for halide exchange is considerably smaller in magnitude in non-polar solvents. The solvation energy difference between halide alkyl ammonium ion-pairs, and between $\mathrm{Pt}^{\mathrm{IV}}$ complex anion alkyl ammonium ion-pairs, e.g. $\left[\mathrm{NR}_{4}\right]_{2}\left[\mathrm{PtCl}_{6}\right]$ and $\left[\mathrm{NR}_{4}\right]_{2}\left[\mathrm{PtCl}_{5} \mathrm{Br}\right]$, in a non-polar solvent is much lower by comparison to the hydration energies of the "bare" anions, e.g. $\left[\mathrm{PtCl}_{6}\right]^{2-}{ }_{(\mathrm{aq})}$, $\left[\mathrm{PtCl}_{5} \mathrm{Br}\right]^{2-}{ }_{(\mathrm{aq})},[\mathrm{Cl}]^{-}{ }_{(\mathrm{aq})}$ and $[\mathrm{Br}]^{-}{ }_{(\mathrm{aq})}$, in water.

Changing the solvent from a polar to non-polar matrix should experimentally reveal the bonding preference of $\mathrm{Pt}^{\mathrm{IV}}$ to chloride above bromide. To confirm this hypothesis a $\mathrm{Pt}^{\mathrm{IV}}$ sample was prepared with the following composition in chloroform; $\left[\mathrm{PtBr}_{6}\right]_{\mathrm{T}}=10 \mathrm{mM}, 0.5 \mathrm{M} \mathrm{Cl}^{-}, 0.5 \mathrm{M} \mathrm{Br}^{-}$and $1.0 \mathrm{M}$ Aliquat-336. The sample was left for 8 weeks to equilibrate at $294 \mathrm{~K}$. The ion-pair-RP-HPLC-UV-Vis chromatographic trace obtained after the injection of $2 \mu \mathrm{l}$ of this sample is shown in Fig. 6 and the subsequent periodic injection of this sample

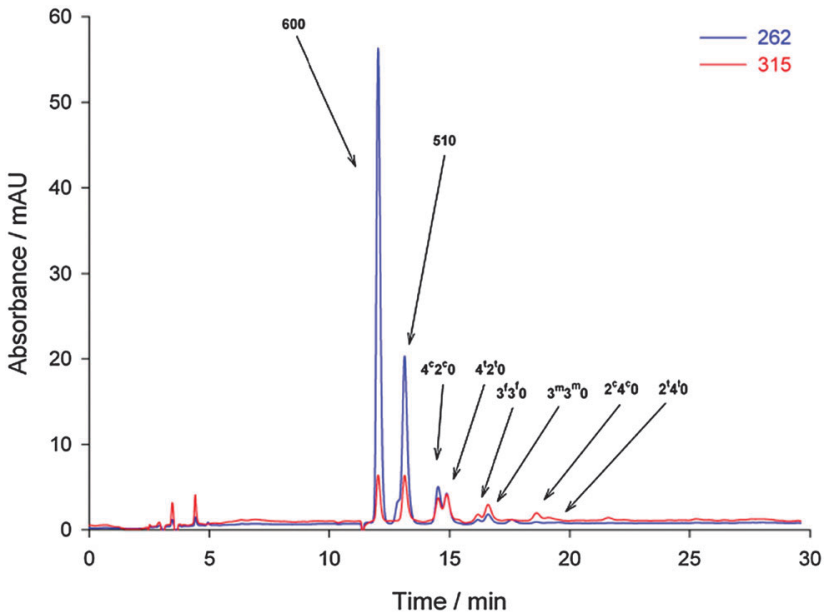

Fig. 6 Ion-pair-RP-HPLC-UV-Vis chromatographic trace depicting the $\left[\mathrm{PtCl}_{6-n} \mathrm{Br}_{n}\right]^{2-}(n=0-6)$ complex anions species distribution in chloroform containing equal portions of methyltrioctylammonium chloride and bromide (Aliquat-336) such that the total halide concentration was $1.0 \mathrm{M},[\mathrm{Pt}]_{\mathrm{T}}=$ $10 \mathrm{mM}$ and the $\mathrm{Cl}^{-}$to $\mathrm{Br}^{-}$mole ratio equal to $1: 1$

for another 3 weeks exhibited no change. By contrast to the earlier observed species distribution obtained in water (Fig. 1 and 4) in which no $\left[\mathrm{PtCl}_{6}\right]^{2-}$ species was observed at $\alpha_{\mathrm{Br}^{-}}=0.5$ in the former sample, the $\left[\mathrm{PtCl}_{6}\right]^{2-}$ complex anion dominates and no $\left[\mathrm{PtBr}_{6}\right]^{2-}$ species is observed, confirming our hypothesis, Fig. 6.

In response to a similar argument regarding metal cation bonding preferences in non-polar solvents and the validity of the HSAB principle, the HSAB concept was defended by Pearson ${ }^{5}$ in 1995 as follows: "It was carefully pointed out by me in ref. 1 that the sequences would be quite different in the gas phase. Thus $\mathrm{F}^{-}$forms stronger bonds to all cationic acids in the gas phase, then $\mathrm{I}^{-}$does. It was because the hydration energy of $\mathrm{F}^{-}$is $50 \mathrm{kcal}$ greater than for $\mathrm{I}^{-}$, that inversions in water would occur." ... "For solvents less polar than water, the difference in the heats of solvation for $\mathrm{F}^{-}$and $\mathrm{I}^{-}$would be less than $50 \mathrm{kcal}$, and inversions in order might not occur. As a result, some authors have reported that the HSAB Principle has failed, because for a metal ion such as $\mathrm{Rh}(\mathrm{I})$ or $\mathrm{Pt}(\mathrm{II})$ the order $\mathrm{CI}>$ $\mathrm{Br}>\mathrm{I}$ is found in some non-aqueous solvents. On the contrary, the HSAB Principle predicts this result." In these passages Pearson argues that halide hydration energy is the reason why $\mathrm{Rh}$ (I) or Pt(II) prefer to bond with the corresponding heavier halide in aqueous solution and indirectly that these metal cations are classified as class (b) irrespective of the interactions existing in the acid-base complex. At this point it is worth re-iterating that Pearson clearly states that hydration/solvation cannot be the reason why two classes of acids and bases exist. The question we pose is for how many class (b) metal cations, already three $\mathrm{Pt}^{\mathrm{IV}}, \mathrm{Rh}^{\mathrm{I}}$ and $\mathrm{Pt}^{\mathrm{II}}$, must it be shown that they are classified as class (b) due to halide hydration energies and not due to the interactions existing in the acid-base complex before it is accepted that HSAB is fundamentally flawed in terms of trying to group metal cations into two classes. 
Table 5 The $\Delta \Delta G_{\mathrm{f}(\text { halide) }}^{0}$ and $\Delta \Delta G_{\mathrm{f}(\mathrm{complex})}^{0}$ contribution towards $\Delta G_{\mathrm{rxn}}^{0}$ w.r.t. halido substitution reactions as defined in eqn (23) - (25) ${ }^{24 a}$

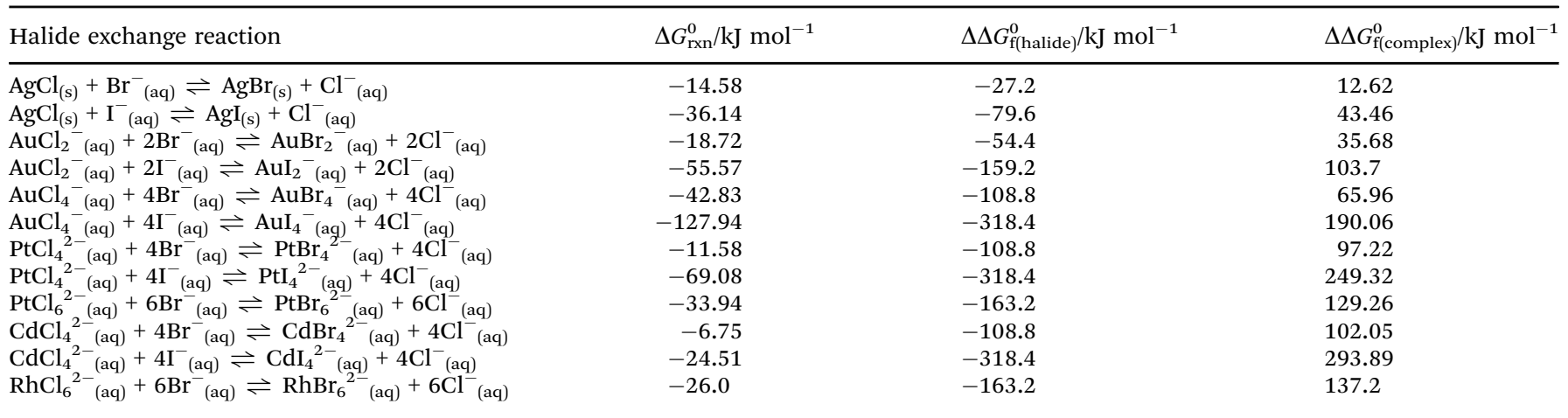

${ }^{a}$ Apart from $\mathrm{Pt}^{\mathrm{IV}}$ halide exchange reactions, all Gibbs energy terms were calculated using electrochemical data in ref. 24 .

A method to show experimentally that all class (b) cations form thermodynamically stable halido complexes in the order $\mathrm{F}^{-} \gg \mathrm{Cl}^{-}>\mathrm{Br}^{-}>\mathrm{I}^{-}$, irrespective of the sample matrix, is to evaluate that the $\Delta \Delta G_{\mathrm{f}(\mathrm{complex})}^{0}$ term contribution towards $\Delta G_{\mathrm{rxn}}^{0}$, i.e. if $\Delta \Delta G_{\mathrm{f}(\text { complex) }}^{0}$ yields a positive value and $\Delta G_{\mathrm{rxn}}^{0}$ is negative, then the lighter halido complexes are thermodynamically favoured and vice versa. Note, we use the convention that a lighter halide is always replaced by a heavier halide. The set of metal cations chosen consist of $\mathrm{Ag}^{+}, \mathrm{Au}^{+}, \mathrm{Au}^{3+}, \mathrm{Rh}^{3+}$, $\mathrm{Cd}^{2+}, \mathrm{Pt}^{2+}$ and $\mathrm{Pt}^{4+}$ which are all well-known soft or class (b) cations. Table 5 summarizes the results obtained for the set of halide exchange reactions tested and in all cases the $\Delta \Delta G_{\mathrm{f}(\mathrm{complex})}^{0}$ term yielded relatively large positive values, implying that lighter metal halido complexes are thermodynamically favoured above the heavier metal halido analogues in aqueous solution and in the case of $\mathrm{Ag}^{+}$even when solid phases are also taken into account. Furthermore, in each case the $\Delta \Delta G_{\mathrm{f}(\text { complex) }}^{0}$ term is largely positive when a chlorido ligand is replaced by iodo compared to when chlorido is replaced by a bromido ligand. The negative $\Delta G_{\mathrm{rxn}(i)}^{0}$ for these halide exchange reactions illustrates that halide hydration energies and not the interactions existing in the acid-base complex determines whether a species is classified as hard or soft in the HSAB conjecture.

Further confirmation of these results are obtained from quantum computational thermodynamic data, using DFT, pertaining to $\mathrm{Pt}^{\mathrm{IV}}$ (Table S1), $\mathrm{Al}^{\mathrm{III}}, \mathrm{Pt}^{\mathrm{II}}, \mathrm{Rh}^{\mathrm{III}}$ (Table S2), $\mathrm{Au}^{3+}$, $\mathrm{Fe}^{3+}, \mathrm{Cd}^{2+}, \mathrm{Sn}^{2+}, \mathrm{Zn}^{2+}$ (Table S3) listed in the ESI. $\dagger$ From the $\Delta \Delta G_{\mathrm{f}(\mathrm{complex})}^{0}$ data shown in Tables S1 and S3 (ESI $\dagger$ ), one distinctive trend emerges in that all $\Delta \Delta G_{\mathrm{f}(\mathrm{complex})}^{0}$ values are positive. This remains the same irrespective of the metal cation oxidation state, DFT functional used, basis set size, the spin-multiplicity of a complex (when in question all spin-multiplicity cases were evaluated), omission or inclusion of relativistic effects and for both gas and simulated solvent phases.

In the above context we conclude that only one 'class' of metal cations exist, i.e. irrespective of the metal cation oxidation state and matrix composition all energetically favour to form thermodynamically stable halido complexes in the order $\mathrm{F}^{-} \gg \mathrm{Cl}^{-}>\mathrm{Br}^{-}>\mathrm{I}^{-}$. The '2nd group' or class (b) species as defined by Ahrland and Pearson only appears when the
$\Delta \Delta G_{\mathrm{f}(\text { halide) }}^{0}$ contribution, i.e. halide hydration energies, towards $\Delta G_{\mathrm{rxn}}^{0}$ exceed the $\Delta \Delta G_{\mathrm{f}(\mathrm{complex})}^{0}$ contribution.

The HSAB principle proposes that only certain cations would prefer to bond with "class (a)" ligands, using HSAB terminology, where in fact the opposite is true. HSAB not only obscures this fact which clearly inhibits inorganic/organometallic synthetic methodology but also hints at subtle chemical phenomena which does not exist.

\section{Conclusions}

In contrast to what HSAB "predicts", the thermodynamic driving force for the replacement of chloride by bromide for each individual ligand exchange reaction present in the $\mathrm{Pt}^{\mathrm{IV}}$ HERN in solution is due to the $\Delta \Delta G_{\text {f(halide) }}^{0}$ energetic contribution, i.e. the difference in halide hydration energy, towards $\Delta G_{\mathrm{rxn}}^{0}$ that exceed the $\Delta \Delta G_{\mathrm{f}(\text { (omplex) }}^{0}$ contribution. With the aid of a generalized thermodynamic test calculation and in conjunction with DFT calculations it was shown that the class (b) metal cations $\mathrm{Ag}^{+}, \mathrm{Au}^{+}, \mathrm{Au}^{3+}, \mathrm{Rh}^{3+}, \mathrm{Cd}^{2+}, \mathrm{Pt}^{2+}, \mathrm{Pt}^{4+}, \mathrm{Fe}^{3+}, \mathrm{Cd}^{2+}, \mathrm{Sn}^{2+}$ and $\mathrm{Zn}^{2+}$ form thermodynamically stable halido complexes in the order $\mathrm{F}^{-} \gg \mathrm{Cl}^{-}>\mathrm{Br}^{-}>\mathrm{I}^{-}$irrespective of the sample matrix. This result is the exact opposite of what the HSAB principle predicts. It turns out that the hydration/solvation energies of halides is the reason why metal cations are categorized into two classes in the HSAB principle and not interactions present in the acid-base complexes. We propose that a care-full consideration of hydration/solvation energies concerning the reactant and product species could alleviate many problematic synthetic procedures.

\section{Computational methods}

Calculation of a complete speciation diagram. To calculate the complex anion molar extinction coefficients, $\varepsilon_{i}$, and the 17 stability constants for the system shown in Scheme $1 \mathrm{~b}$ it was necessary to develop a set of routines (called program EquiState.exe) in the Matlab 7.01 environment. The general workflow of program Equistate.exe is similar to that described by Meloun et al. ${ }^{6}$ with some expected differences. The set of simultaneous non-linear mass balance equations derived from 
the model, Scheme 1b, are iteratively solved using the NewtonRaphson algorithm ${ }^{25}$ to obtain the $\left[\mathrm{PtCl}_{6}\right]^{2-}$ and free unbound $\left[\mathrm{Cl}^{-}\right]$and $\left[\mathrm{Br}^{-}\right]$concentrations. Differentiating the non-linear least-squares objective function, eqn (26), firstly with respect to overall formation constants and then w.r.t. molar extinction coefficients yields the $n \times n$ Jacobian matrixes, $J(\beta)$ and $J(\varepsilon)$ respectively. Because we obtain a response signal with "no overlap" for each of the $10 \mathrm{Pt}^{\mathrm{IV}}$ species the $J(\beta)$ and $J(\varepsilon)$ matrices only have entries (partial derivatives) along the diagonal simplifying matters considerably. This is in contrast to cases where a composite signal is obtained, e.g. spectral overlap in UV-Vis spectra when several species are present, and results in $J(\beta)$ and $J(\varepsilon)$ to each have $n \times n$ entries. $^{6}$

$$
S=\sum_{i=1}^{j}\left(A_{\text {experimental }(j)}-A_{\text {theoretical }(j)}\right)^{2}
$$

Utilizing the above procedure, the stability constants $K_{i}(i=1-10)$ as defined in Scheme $1 \mathrm{~b}$ can be computed. Note, since eqn (16) contains the term $\left(\beta_{8} \vee \beta_{9}\right)$ the above procedure must be repeated with the difference that the set of simultaneous non-linear mass balance equations derived from the model, Scheme $1 \mathrm{~b}$, are now expressed in terms of $\left[\mathrm{PtBr}_{6}\right]^{2-}$ and free unbound $\left[\mathrm{Cl}^{-}\right]$and $\left[\mathrm{Br}^{-}\right]$concentrations.

The 7 stability constants $K_{i}(i=11-17)$ pertaining to isomerisation and 'cross' ligand exchange reactions are now numerically 'fixed' since the standard reaction Gibbs free energy is a state function. The $K_{i}(i=11-17)$ are calculated as shown in the following two examples. Consider the stepwise ligand exchange reactions associated with $K_{2}$ and $K_{3}$ shown in scheme $1 \mathrm{~b}$. Dividing their stability constant equations results in eqn (27) and in effect accounts for the isomerisation reaction between cis- $\left[\mathrm{PtCl}_{4} \mathrm{Br}_{2}\right]^{2-}$ and trans- $\left[\mathrm{PtCl}_{4} \mathrm{Br}_{2}\right]^{2-}$.

$$
\begin{aligned}
\frac{K_{2}}{K_{3}}= & \frac{\frac{\left[\text { cis }-\mathrm{PtCl}_{4} \mathrm{Br}_{2}{ }^{2-}\right]\left[\mathrm{Cl}^{-}\right]}{\left[\mathrm{PtCl}_{5} \mathrm{Br}^{2-}\right]\left[\mathrm{Br}^{-}\right]}}{\frac{\left[\text { trans }-\mathrm{PtCl}_{4} \mathrm{Br}_{2}{ }^{2-}\right]\left[\mathrm{Cl}^{-}\right]}{\left[\mathrm{PtCl}_{5} \mathrm{Br}^{2-}\right]\left[\mathrm{Br}^{-}\right]}} \\
& =\frac{\left[\text { cis }-\mathrm{PtCl}_{4} \mathrm{Br}_{2}{ }^{2-}\right]}{\left[\text { trans }-\mathrm{PtCl}_{4} \mathrm{Br}_{2}{ }^{2-}\right]} \\
& =K_{11}
\end{aligned}
$$

Moreover, the 'cross' ligand substitution reaction stability constants were calculated by making use of reaction 'loops' that contain a 'cross' ligand exchange reaction, e.g. trans$\left[\mathrm{PtCl}_{4} \mathrm{Br}_{2}\right]^{2-} \rightarrow$ cis- $\left[\mathrm{PtCl}_{4} \mathrm{Br}_{2}\right]^{2-} \rightarrow$ mer- $\left[\mathrm{PtCl}_{3} \mathrm{Br}_{3}\right]^{2-} \rightarrow$ trans$\left[\mathrm{PtCl}_{4} \mathrm{Br}_{2}\right]^{2-}$, resulting in eqn (28) which on rearrangement gives eqn (29), accounting for the step-wise stability constant for a 'cross' ligand exchange reaction.

$$
\begin{aligned}
K_{11} \times K_{15} \times \frac{1}{K_{4}}= & \frac{\left[\text { cis }-\mathrm{PtCl}_{4} \mathrm{Br}_{2}{ }^{2-}\right]}{\left[\text { trans }-\mathrm{PtCl}_{2} \mathrm{Br}_{4}{ }^{2-}\right]} \times \frac{\left[\text { mer }-\mathrm{PtCl}_{3} \mathrm{Br}_{3}{ }^{2-}\right]\left[\mathrm{Cl}^{-}\right]}{\left[\text {cis }-\mathrm{PtCl}_{4} \mathrm{Br}_{2}{ }^{2-}\right]\left[\mathrm{Br}^{-}\right]} \\
& \times \frac{\left[\text { trans }-\mathrm{PtCl}_{4} \mathrm{Br}_{2}{ }^{2-}\right]\left[\mathrm{Br}^{-}\right]}{\left[\text {mer }-\mathrm{PtCl}_{3} \mathrm{Br}_{3}{ }^{2-}\right]\left[\mathrm{Cl}^{-}\right]}=1
\end{aligned}
$$

$$
K_{15}=\frac{K_{4}}{K_{11}}=\frac{\left[\text { mer }-\mathrm{PtCl}_{3} \mathrm{Br}_{3}{ }^{2-}\right]\left[\mathrm{Cl}^{-}\right]}{\left[\text {cis }-\mathrm{PtCl}_{4} \mathrm{Br}_{2}^{2-}\right]\left[\mathrm{Br}^{-}\right]}
$$

Derivation of eqn (3)-(7) is included here for clarity.

$$
\begin{gathered}
K_{1}^{*}=K_{1}=\frac{\left(\left[\mathrm{PtCl}_{5} \mathrm{Br}\right]^{2-}\right)\left([\mathrm{Cl}]^{-}\right)}{\left(\left[\mathrm{PtCl}_{6}\right]^{2-}\right)\left([\mathrm{Br}]^{-}\right)} \\
K_{2}{ }^{*}=K_{2}+K_{3}=\frac{\text { cis- }\left(\left[\mathrm{PtCl}_{4} \mathrm{Br}_{2}\right]^{2-}\right)\left([\mathrm{Cl}]^{-}\right)}{\left(\left[\mathrm{PtCl}_{5} \mathrm{Br}\right]^{2-}\right)\left([\mathrm{Br}]^{-}\right)} \\
+\frac{\operatorname{trans}^{-}\left(\left[\mathrm{PtCl}_{4} \mathrm{Br}_{2}\right]^{2-}\right)\left([\mathrm{Cl}]^{-}\right)}{\left(\left[\mathrm{PtCl}_{5} \mathrm{Br}\right]^{2-}\right)\left([\mathrm{Br}]^{-}\right)} \\
=\frac{\left(\left[\mathrm{PtCl}_{4} \mathrm{Br}_{2}\right]^{2-}\right)\left([\mathrm{Cl}]^{-}\right)}{\left(\left[\mathrm{PtCl}_{5} \mathrm{Br}^{2-}\right)\left([\mathrm{Br}]^{-}\right)\right.}
\end{gathered}
$$

where cis- $\left(\left[\mathrm{PtCl}_{4} \mathrm{Br}_{2}\right]\right)^{2-}+$ trans $-\left(\left[\mathrm{PtCl}_{4} \mathrm{Br}_{2}\right]\right)^{2-}=\left(\left[\mathrm{PtCl}_{4} \mathrm{Br}_{2}\right]\right)^{2-}$

$K_{3}{ }^{*}=\frac{f a c-\left(\left[\mathrm{PtCl}_{3} \mathrm{Br}_{3}\right]^{2-}\right)\left([\mathrm{Cl}]^{-}\right)+\text {mer }-\left(\left[\mathrm{PtCl}_{3} \mathrm{Br}_{3}\right]^{2-}\right)\left([\mathrm{Cl}]^{-}\right)}{\text {cis }-\left(\left[\mathrm{PtCl}_{4} \mathrm{Br}_{2}\right]^{2-}\right)\left([\mathrm{Br}]^{-}\right)+\text {trans }-\left(\left[\mathrm{PtCl}_{4} \mathrm{Br}_{2}\right]^{2-}\right)\left([\mathrm{Br}]^{-}\right)}$ where $f a c-\left(\left[\mathrm{PtCl}_{3} \mathrm{Br}_{3}\right]^{2-}\right)+$ mer- $\left(\left[\mathrm{PtCl}_{3} \mathrm{Br}_{3}\right]^{2-}\right)=\left(\left[\mathrm{PtCl}_{3} \mathrm{Br}_{3}\right]^{2-}\right)$

$$
=\frac{f a c-\left(\left[\mathrm{PtCl}_{3} \mathrm{Br}_{3}\right]^{2-}\right)\left([\mathrm{Cl}]^{-}\right)+\text {mer }-\left(\left[\mathrm{PtCl}_{3} \mathrm{Br}_{3}\right]^{2-}\right)\left([\mathrm{Cl}]^{-}\right)}{\left(\left[\mathrm{PtCl}_{4} \mathrm{Br}_{2}\right]^{2-}\right)\left([\mathrm{Br}]^{-}\right)}
$$$$
=\frac{\text { fac }-\left(\left[\mathrm{PtCl}_{3} \mathrm{Br}_{3}\right]^{2-}\right)\left([\mathrm{Cl}]^{-}\right)+\text {mer }-\left(\left[\mathrm{PtCl}_{3} \mathrm{Br}_{3}\right]^{2-}\right)\left([\mathrm{Cl}]^{-}\right)}{K_{2}{ }^{*}\left(\left[\mathrm{PtCl}_{5} \mathrm{Br}\right]^{2-}\right)\left([\mathrm{Br}]^{-}\right) \frac{\left([\mathrm{Br}]^{-}\right)}{\left([\mathrm{Cl}]^{-}\right)}}
$$$$
=\frac{f a c-\left(\left[\mathrm{PtCl}_{3} \mathrm{Br}_{3}\right]^{2-}\right)\left([\mathrm{Cl}]^{-}\right)}{K_{2} *\left(\left[\mathrm{PtCl}{ }_{5} \mathrm{Br}\right]^{2-}\right)\left([\mathrm{Br}]^{-}\right) \frac{\left([\mathrm{Br}]^{-}\right)}{\left([\mathrm{Cl}]^{-}\right)}}
$$$$
+\frac{\operatorname{mer}-\left(\left[\mathrm{PtCl}_{3} \mathrm{Br}_{3}\right]^{2-}\right)\left([\mathrm{Cl}]^{-}\right)}{K_{2} *\left(\left[\mathrm{PtCl}_{5} \mathrm{Br}\right]^{2-}\right)\left([\mathrm{Br}]^{-}\right) \frac{\left([\mathrm{Br}]^{-}\right)}{\left([\mathrm{Cl}]^{-}\right)}}
$$

$$
=\frac{f a c-\left(\left[\mathrm{PtCl}_{3} \mathrm{Br}_{3}\right]^{2-}\right)\left([\mathrm{Cl}]^{-}\right)^{2}}{K_{2} *\left(\left[\mathrm{PtCl}{ }_{5} \mathrm{Br}\right]^{2-}\right)\left([\mathrm{Br}]^{-}\right)^{2}}+\frac{m e r-\left(\left[\mathrm{PtCl}_{3} \mathrm{Br}_{3}\right]^{2-}\right)\left([\mathrm{Cl}]^{-}\right)^{2}}{K_{2} *\left(\left[\mathrm{PtCl}_{5} \mathrm{Br}\right]^{2-}\right)\left([\mathrm{Br}]^{-}\right)^{2}}
$$

where $K_{2} K_{4}=\frac{\text { cis- }\left(\left[\mathrm{PtCl}_{4} \mathrm{Br}_{2}\right]^{2-}\right)\left([\mathrm{Cl}]^{-}\right) \text {fac }-\left(\left[\mathrm{PtCl}_{3} \mathrm{Br}_{3}\right]^{2-}\right)\left([\mathrm{Cl}]^{-}\right)}{\left(\left[\mathrm{PtCl}_{5} \mathrm{Br}\right]^{2-}\right)\left([\mathrm{Br}]^{-}\right) c i s_{-}\left(\left[\mathrm{PtCl}_{4} \mathrm{Br}_{2}\right]^{2-}\right)\left([\mathrm{Br}]^{-}\right)}$

$$
=\frac{f a c-\left(\left[\mathrm{PtCl}_{3} \mathrm{Br}_{3}\right]^{2-}\right)\left([\mathrm{Cl}]^{-}\right)^{2}}{\left(\left[\mathrm{PtCl}_{5} \mathrm{Br}\right]^{2-}\right)\left([\mathrm{Br}]^{-}\right)^{2}} \text { and }
$$

$$
\begin{aligned}
K_{3} K_{5} & =\frac{\text { trans }-\left(\left[\mathrm{PtCl}_{4} \mathrm{Br}_{2}\right]^{2-}\right)\left([\mathrm{Cl}]^{-}\right) \text {mer }-\left(\left[\mathrm{PtCl}_{3} \mathrm{Br}_{3}\right]^{2-}\right)\left([\mathrm{Cl}]^{-}\right)}{\left(\left[\mathrm{PtCl}{ }_{5} \mathrm{Br}\right]^{2-}\right)\left([\mathrm{Br}]^{-}\right) \text {trans }-\left(\left[\mathrm{PtCl}_{4} \mathrm{Br}_{2}\right]^{2-}\right)\left([\mathrm{Br}]^{-}\right)} \\
& =\frac{\text { mer }-\left(\left[\mathrm{PtCl}_{3} \mathrm{Br}_{3}\right]^{2-}\right)\left([\mathrm{Cl}]^{-}\right)^{2}}{\left(\left[\mathrm{PtCl}_{5} \mathrm{Br}\right]^{2-}\right)\left([\mathrm{Br}]^{-}\right)^{2}} \text { substituting for } K_{2} K_{4} \text { and } K_{3} K_{5} \\
& =\frac{K_{2} K_{4}}{K_{2}{ }^{*}}+\frac{K_{3} K_{5}}{K_{2}{ }^{*}}=\frac{\left(\left[\mathrm{PtCl}_{3} \mathrm{Br}_{3}\right]^{2-}\right)\left([\mathrm{Cl}]^{-}\right)}{\left(\left[\mathrm{PtCl}_{4} \mathrm{Br}_{2}\right]^{2-}\right)\left([\mathrm{Br}]^{-}\right)}
\end{aligned}
$$




$$
\begin{aligned}
& K_{4}^{*}=\frac{\text { cis- }-\left(\left[\mathrm{PtCl}_{2} \mathrm{Br}_{4}\right]^{2-}\right)\left([\mathrm{Cl}]^{-}\right)+\text {trans }-\left(\left[\mathrm{PtCl}_{2} \mathrm{Br}_{4}\right]^{2-}\right)\left([\mathrm{Cl}]^{-}\right)}{\text {fac- }\left(\left[\mathrm{PtCl}_{3} \mathrm{Br}_{3}\right]^{2-}\right)\left([\mathrm{Br}]^{-}\right)+\text {mer }-\left(\left[\mathrm{PtCl}_{3} \mathrm{Br}_{3}\right]^{2-}\right)\left([\mathrm{Br}]^{-}\right)} \\
& \text {where cis- }\left(\left[\mathrm{PtCl}_{2} \mathrm{Br}_{4}\right]^{2-}\right)+\text { trans- }\left(\left[\mathrm{PtCl}_{2} \mathrm{Br}_{4}\right]^{2-}\right)=\left(\left[\mathrm{PtCl}_{2} \mathrm{Br}_{4}\right]^{2-}\right) \\
& =\frac{\text { cis }-\left(\left[\mathrm{PtCl}_{2} \mathrm{Br}_{4}\right]^{2-}\right)\left([\mathrm{Cl}]^{-}\right)+\text {trans }-\left(\left[\mathrm{PtCl}_{2} \mathrm{Br}_{4}\right]^{2-}\right)\left([\mathrm{Cl}]^{-}\right)}{K_{3} *\left(\text { cis }-\left(\left[\mathrm{PtCl}_{4} \mathrm{Br}_{2}\right]^{2-}\right)+\text { trans }-\left(\left[\mathrm{PtCl}_{4} \mathrm{Br}_{2}\right]^{2-}\right)\right) \frac{\left([\mathrm{Br}]^{-}\right)^{2}}{\left([\mathrm{Cl}]^{-}\right)}} \\
& =\frac{\text { cis }-\left(\left[\mathrm{PtCl}_{2} \mathrm{Br}_{4}\right]^{2-}\right)\left([\mathrm{Cl}]^{-}\right)^{2}+\text { trans }-\left(\left[\mathrm{PtCl}_{2} \mathrm{Br}_{4}\right]^{2-}\right)\left([\mathrm{Cl}]^{-}\right)^{2}}{K_{3}{ }^{*}\left(\text { cis }-\left(\left[\mathrm{PtCl}_{4} \mathrm{Br}_{2}\right]^{2-}\right)\left([\mathrm{Br}]^{-}\right)^{2}+\text { trans }-\left(\left[\mathrm{PtCl}_{4} \mathrm{Br}_{2}\right]^{2-}\right)\left([\mathrm{Br}]^{-}\right)^{2}\right)} \\
& =\frac{\text { cis }-\left(\left[\mathrm{PtCl}_{2} \mathrm{Br}_{4}\right]^{2-}\right)\left([\mathrm{Cl}]^{-}\right)^{2}+\text { trans }-\left(\left[\mathrm{PtCl}_{2} \mathrm{Br}_{4}\right]^{2-}\right)\left([\mathrm{Cl}]^{-}\right)^{2}}{K_{2}{ }^{*} K_{3} *\left(\left[\mathrm{PtCl}_{5} \mathrm{Br}\right]^{2-}\right) \frac{\left([\mathrm{Br}]^{-}\right)^{3}}{\left([\mathrm{Cl}]^{-}\right)}} \\
& =\frac{\text { cis }-\left(\left[\mathrm{PtCl}_{2} \mathrm{Br}_{4}\right]^{2-}\right)\left([\mathrm{Cl}]^{-}\right)^{3}+\text { trans }-\left(\left[\mathrm{PtCl}_{2} \mathrm{Br}_{4}\right]^{2-}\right)\left([\mathrm{Cl}]^{-}\right)^{3}}{K_{2}{ }^{*} K_{3}{ }^{*}\left(\left[\mathrm{PtCl}_{5} \mathrm{Br}\right]^{2-}\right)\left([\mathrm{Br}]^{-}\right)^{3}} \\
& =\frac{\text { cis }-\left(\left[\mathrm{PtCl}_{2} \mathrm{Br}_{4}\right]^{2-}\right)\left([\mathrm{Cl}]^{-}\right)^{3}}{K_{2}{ }^{*} K_{3} *\left(\left[\mathrm{PtCl}{ }_{5} \mathrm{Br}\right]^{2-}\right)\left([\mathrm{Br}]^{-}\right)^{3}}+\frac{\text { trans }-\left(\left[\mathrm{PtCl}_{2} \mathrm{Br}_{4}\right]^{2-}\right)\left([\mathrm{Cl}]^{-}\right)^{3}}{K_{2}{ }^{*} K_{3} *\left(\left[\mathrm{PtCl}_{5} \mathrm{Br}\right]^{2-}\right)\left([\mathrm{Br}]^{-}\right)^{3}} \\
& \text { where } K_{2} K_{4} K_{6}=\frac{\text { cis- }\left(\left[\mathrm{PtCl}_{4} \mathrm{Br}_{2}\right]^{2-}\right)\left([\mathrm{Cl}]^{-}\right) \text {fac }-\left(\left[\mathrm{PtCl}_{3} \mathrm{Br}_{3}\right]^{2-}\right)\left([\mathrm{Cl}]^{-}\right) \text {cis- }\left(\left[\mathrm{PtCl}_{2} \mathrm{Br}_{4}\right]^{2-}\right)\left([\mathrm{Cl}]^{-}\right)}{\left(\left[\mathrm{PtCl}_{5} \mathrm{Br}\right]^{2-}\right)\left([\mathrm{Br}]^{-}\right) \text {cis }-\left(\left[\mathrm{PtCl}_{4} \mathrm{Br}_{2}\right]^{2-}\right)\left([\mathrm{Br}]^{-}\right) \text {fac }-\left(\left[\mathrm{PtCl}_{3} \mathrm{Br}_{3}\right]^{2-}\right)\left([\mathrm{Br}]^{-}\right)} \\
& =\frac{\text { cis }-\left(\left[\mathrm{PtCl}_{2} \mathrm{Br}_{4}\right]^{2-}\right)\left([\mathrm{Cl}]^{-}\right)^{3}}{\left(\left[\mathrm{PtCl}{ }_{5} \mathrm{Br}\right]^{2-}\right)\left([\mathrm{Br}]^{-}\right)^{3}} \\
& \text { and } K_{3} K_{5} K_{7}=\frac{\text { trans }-\left(\left[\mathrm{PtCl}_{4} \mathrm{Br}_{2}\right]^{2-}\right)\left([\mathrm{Cl}]^{-}\right) \text {mer }-\left(\left[\mathrm{PtCl}_{3} \mathrm{Br}_{3}\right]^{2-}\right)\left([\mathrm{Cl}]^{-}\right) \text {trans }-\left(\left[\mathrm{PtCl}_{2} \mathrm{Br}_{4}\right]^{2-}\right)\left([\mathrm{Cl}]^{-}\right)}{\left(\left[\mathrm{PtCl}_{5} \mathrm{Br}\right]^{2-}\right)\left([\mathrm{Br}]^{-}\right) \text {trans }-\left(\left[\mathrm{PtCl}_{4} \mathrm{Br}_{2}\right]^{2-}\right)\left([\mathrm{Br}]^{-}\right) \text {mer }-\left(\left[\mathrm{PtCl}_{3} \mathrm{Br}_{3}\right]^{2-}\right)\left([\mathrm{Cl}]^{-}\right)} \\
& =\frac{\text { trans }-\left(\left[\mathrm{PtCl}_{2} \mathrm{Br}_{4}\right]^{2-}\right)\left([\mathrm{Cl}]^{-}\right)^{3}}{\left(\left[\mathrm{PtCl}{ }_{5} \mathrm{Br}\right]^{2-}\right)\left([\mathrm{Br}]^{-}\right)^{3}} \text { substituting for } K_{2} K_{4} K_{6} \text { and } K_{3} K_{5} K_{7} \\
& =\frac{K_{2} K_{4} K_{6}}{K_{2}{ }^{*} K_{3}{ }^{*}}+\frac{K_{3} K_{5} K_{7}}{K_{2}{ }^{*} K_{3}{ }^{*}}=\frac{\left(\left[\mathrm{PtCl}_{2} \mathrm{Br}_{4}\right]^{2-}\right)\left([\mathrm{Cl}]^{-}\right)}{\left(\left[\mathrm{PtCl}_{3} \mathrm{Br}_{3}\right]^{2-}\right)\left([\mathrm{Br}]^{-}\right)}
\end{aligned}
$$

The derivation of $K_{5}{ }^{*}$ follows the same procedure as above with the exception that only one reaction route must be chosen or else the concentration of $\left[\mathrm{PtClBr}_{5}\right]^{2-}$ will be twice the correct value and hence the "or" sign in eqn (7).

$$
K_{5}{ }^{*}=\frac{K_{2} K_{4} K_{6} K_{8}}{K_{2}{ }^{*} K_{3}{ }^{*} K_{4}{ }^{*}} \vee \frac{K_{3} K_{5} K_{7} K_{9}}{K_{2}{ }^{*} K_{3}{ }^{*} K_{4}{ }^{*}}=\frac{\left(\left[\mathrm{PtClBr}_{5}\right]^{2-}\right)\left([\mathrm{Cl}]^{-}\right)}{\left(\left[\mathrm{PtCl}_{2} \mathrm{Br}_{4}\right]^{2-}\right)\left([\mathrm{Br}]^{-}\right)}
$$

DFT and WFT computational details. Geometries were fully optimised at the relativistic spin-orbit ZORA level, using the $\mathrm{LDA}^{26}{ }^{26} \mathrm{GGA}^{\prime} \mathrm{PB} \mathrm{PB}^{27}$ and PW91, ${ }^{28}$ and the M06L ${ }^{29}$ functionals, together with an all-electron quadruple- $\zeta$ plus polarisation function (QZ4P) basis set on the Pt and I and even-tempered pVQZ basis set on the $\mathrm{F}, \mathrm{Cl}$ and $\mathrm{Br}$ atoms. Optimization in the gas phase as well as for those using the conductor-like screening model (COSMO), ${ }^{30}$ with the parameters of water, were done with the abovementioned combinations of DFT functionals and basis sets. The obtained structures were characterized as minima by analysing the Hessian matrix. These calculations employed the ADF2010.02 program. $^{31}$
Geometries were fully optimised at the DFT (LSDA, PBEVWN, M06L, B3LYP, PBE1PBE, M06, CAM-B3LYP and HSEH1PBE) and MP2 levels of theory using the LanL2DZ basis set in both the gas phase as well as for those using Polarizable Continuum Model (PCM), with the parameters of water. The obtained structures were characterized as minima by analyzing the Hessian matrix. These calculations employed the Gaussian 09, Revision B.01 program. $^{32}$

\section{Experimental}

\section{Reagents}

HPLC grade acetonitrile was obtained from Merck (608-001-00-3). All aqueous solutions were prepared using ultrapure Milli-Q water ( $>18 \mathrm{M} \Omega$ ). Analytical grade purity tetrabutyl-ammonium chloride (TBACl), sodium acetate and glacial acetic acid were obtained from Sigma-Aldrich. Mobile phases were prepared by the addition of acetonitrile to stock solutions of $0.05 \mathrm{M}$ tetrabutyl-ammonium chloride and $0.1 \mathrm{M}$ acetate buffer $(\mathrm{pH}=4.6)$ to give $48 \%(\mathrm{v} / \mathrm{v})$ $\mathrm{CH}_{3} \mathrm{CN}: \mathrm{H}_{2} \mathrm{O}$ solutions. All mobile phases were filtered through 
$0.45 \mathrm{~m} \mathrm{HV}$ filters (Mil-lipore Corporation, HVLP04700) under vacuum and degassed for $15 \mathrm{~min}$ in an ultrasonic bath before use. $\mathrm{Na}_{2} \mathrm{PtCl}_{6} \cdot 2 \mathrm{H}_{2} \mathrm{O}, \mathrm{H}_{2} \mathrm{PtBr}_{6}$ and $\mathrm{H}_{2} \mathrm{PtCl}_{6}$ (Johnson Matthey PLC, Precious Metals Division) were of analytical reagent grade quality and dried in vacuo and stored in a desiccator prior to use.

\section{IP-HPLC-UV-Vis}

Chromatographic separations were accomplished using a Varian Prostar liquid chromatograph equipped with a binary 210 solvent delivery module, a 410 auto-sampler with a 345 UV-Vis dual wave-length detector. The flow rate was set at $0.8 \mathrm{~mL} \mathrm{~min}^{-1}$ and the absorbance was measured at two fixed wavelengths, namely 262 and $315 \mathrm{~nm}$. The column used throughout this study was a Microsorb $\mathrm{C}_{18}, 250 \mathrm{~mm} \times 4.6 \mathrm{~mm}$ i.d., $5 \mu \mathrm{m}$ particles. Column efficiency was periodically evaluated with the injection of a solution comprising of acetophenone, phenol, aniline, caffeine, uracil, pyridine, benzene and $30 \%(\mathrm{v} / \mathrm{v})$ acetonitrile. Column conditioning comprised of mobile phase passage through the column for 45 min prior to analysis.

\section{ICP-OES analyses}

Determination of the samples' total $\mathrm{Pt}^{\mathrm{IV}}, \mathrm{Cl}^{-}$and $\mathrm{Br}^{-}$concentrations were accomplished using a SPECTRO Arcos ICP-OES spectrometer operating with a RF power set to $1400 \mathrm{~W}$ using a Burgener T2002 nebulizer and a cyclonic spray chamber. The nebulizer flow rate was set at $0.8 \mathrm{~mL} \mathrm{~min}^{-1}$, auxiliary gas flow rate was set to $1 \mathrm{~L} \mathrm{~min}^{-1}$ and coolant flow rate to $13 \mathrm{~L} \mathrm{~min}^{-1}$. Pt standard solutions were prepared from a $1000 \mathrm{ppm} \pm 3 \mathrm{ppm}$ stock solution in a $500 \mathrm{~mL} 10 \% \mathrm{HCl}$ matrix obtained from De Bruyn Spectroscopy (Ultraspec). $\mathrm{Cl}^{-}$and $\mathrm{Br}^{-}$standard solutions were prepared from $\mathrm{NaCl}$ and $\mathrm{NaBr}$ (puriss; 99.9\%) obtained from Sigma-Aldrich, respectively. All standards and samples were matrix matched.

\section{Sample preparations}

Aqueous matrix. 21 samples were prepared in which the bromide mole fraction $\left(\alpha_{\mathrm{Br}^{-}}=\frac{n_{\mathrm{Br}^{-}}}{n_{\mathrm{Br}^{-}}+n_{\mathrm{Cl}^{-}}}\right)$was systematically varied. This stepwise incremental increase was 0.005 for the first 10 samples, and 0.05 for the remainder of the samples. All 21 samples were prepared such that the total $\left[\mathrm{Pt}^{\mathrm{IV}}\right]_{\mathrm{T}}$ concentration of each was $10.0 \mathrm{mM}$. The ionic strength was kept constant for all samples by maintaining a total halide concentration such that $\left[\mathrm{Cl}^{-}\right]+\left[\mathrm{Br}^{-}\right]=1.001 \mathrm{M}$ with $\left[\mathrm{H}_{3} \mathrm{O}^{+}\right]_{\mathrm{T}}=0.2002 \mathrm{M}$ and $\left[\mathrm{Na}^{+}\right]_{\mathrm{T}}=0.7996 \mathrm{M}$.

Organic matrix (chloroform). The mixed $\mathrm{Pt}^{\mathrm{IV}}$ chloridobromido sample in an organic matrix was prepared by dissolving $\mathrm{H}_{2} \mathrm{PtBr}_{6}$ in chloroform containing equal portions of methyltrioctylammonium chloride and bromide (Aliquat-336) such that the total halide concentration was $1.0 \mathrm{M},[\mathrm{Pt}]_{\mathrm{T}}=$ $10 \mathrm{mM}$ and the $\mathrm{Cl}^{-}$to $\mathrm{Br}^{-}$mole ratio was equal to $1: 1$. The bromido form of Aliquat-336 was prepared by washing $20 \%(\mathrm{v} / \mathrm{v})$ Aliquat-336 in chloroform seven fold with 3.0 M HBr.

\section{References}

1 G. Peters, W. Preetz and D. Bublitz, Chem. Rev., 1996, 96, 977.

2 (a) S. Ahraland, Acta Chem. Scand., 1956, 10, 723; (b) S. Ahraland and I. Grenthe, Acta Chem. Scand., 1957, 11, 1111; (c) S. Ahraland, I. Grenthe, L. Johansson and B. Norén, Acta Chem. Scand., 1963, 17, 1567; (d) S. Ahraland and J. Rawsthorne, Acta Chem. Scand., 1970, 24, 157; (e) S. Ahraland and N.-O. Björk, Acta Chem. Scand., 1976, 30, 249; $(f)$ S. Ahraland and B. Tagesson, Acta Chem. Scand., 1977, 31, 615; $(g)$ S. Ahraland, B. Tagesson and D. Tuhtar, Acta Chem. Scand., 1977, 31, 625; (h) S. Ahraland, L. Kullberg and R. Portanova, Acta Chem. Scand., 1978, 32, 251; (i) S. Ahraland, N.-O. Björk and I. Persson, Acta Chem. Scand., 1981, 35, 67; ( $j$ ) S. Ahraland, K. Nilsson and B. Tagesson, Acta Chem. Scand., 1983, 37, 193; (k) S. Ahraland, S. Ishiguro and I. Persson, Acta Chem. Scand., 1986, 40, 418; (l) S. Ahraland, G. Hefter and B. Norén, Acta Chem. Scand., 1990, 44, 1.

3 R. G. Pearson, J. Am. Chem. Soc., 1963, 22, 3533.

4 H. Mayr, M. Breugst and A. R. Ofial, Angew. Chem., Int. Ed., 2011, 50, 6470.

5 R. G. Pearson, Inorg. Chim. Acta, 1995, 240, 93-98.

6 M. Meloun, J. Havel and E. Högfeldt, Computation of Solution Equilibria - A Guide to Methods in Potentiometry, Extraction, and Spectrophotometry, Ellis Horwood, Chichester, 1987.

7 R. Abegg and G. Bodländer, Z. Anorg. Allg. Chem., 1899, 20, 453.

8 J. Bjerrum, Chem. Rev., 1950, 46, 381.

9 H. H. Drews and W. Z. Preetz, Z. Naturforsch. B, 1996, 51, 1563.

10 H. I. Schlesinger and M. W. Tapley, J. Am. Chem. Soc., 1924, 46, 276.

11 I. V. Khmelinski, V. P. Grivin and V. F. Plyusnin, J. Photochem. Photobiol., A, 1990, 51, 379.

12 P.-H. Van Wyk, W. J Gerber and K. R. Koch, Anal. Chim. Acta, 2011, 704, 154.

13 J. P. Foley and M. S. Jeansonne, J. Chromatogr., 1992, 1, 594. 14 A. Wilkinson and G. Cotton, Advanced Inorganic Chemistry, John Wiley \& Sons, New York, 1988.

15 W. J. Gerber, K. R. Koch, H. E. Rohwer, E. C. Hosten and T. E. Geswindt, Talanta, 2010, 82, 348.

16 W. Robb and G. M. Harris, J. Am. Chem. Soc., 1965, 87, 4472. 17 W. Robb and M. M. de V. Steyn, Inorg. Chem., 1967, 6, 616. 18 W. Robb, M. M. de, V. Steyn and H. Kruger, Inorg. Chim. Acta, 1969, 3, 383. 30. extinction coeffieicients.

19 P. R. Varadwaj, I. Cukrowski, C. B. Perry and H. M. Marques, J. Phys. Chem. A, 2011, 115, 6629.

20 M. R. Burger, J. Kramer, H. Chermette and K. R. Koch, Magn. Reson. Chem., 2010, 48, S38-S47.

21 J. Autschbach, Coord. Chem. Rev., 2007, 251, 1796.

22 T. Engel and P. Reid, Thermodynamics, Statistical Thermodynamics and Kinetics, Prentice Hall, Inc., 2006.

23 H. Drews and W. Preetz, Z. Naturforsch., 1997, 52, 435.

24 G. Inzelt, Standard Potentials, Encyclopaedia of Electrochemistry, John Wiley \& Sons, Ltd., 2007. 
25 R. L. Burden and J. D. Faires, Numerical Analysis, Brooks/ Cole Publishing Company, 6th edn, 1997.

26 S. H. Vosko, L. Wilk and M. Nusair, Can. J. Phys., 1980, 58, 1200 .

27 J. P. Perdew, K. Burke and M. Ernzerhof, Phys. Rev. Lett., 1996, 77, 3865.

28 J. P. Perdew, J. A. Chevary, S. H. Vosko, K. A. Jackson, M. R. Pederson, D. J. Sing and C. Fiolhais, Phys. Rev. B: Condens. Matter Mater. Phys., 1992, 46, 6671.

29 (a) Y. Zhao and D. G. Truhlar, J. Chem. Phys., 2006, 125, 194101; (b) Y. Zhao and D. G. Truhlar, Theor. Chem. Acc., 2008, 120, 215.

30 (a) A. Klamt and G. Schüürmann, J. Chem. Soc., Perkin Trans. 2, 1993, 799; (b) A. Klamt, J. Phys. Chem., 1995, 99, 2224; (c) A. Klamt and V. Jonas, J. Chem. Phys., 1996, 105, 9972.

31 E. J. Baerends, T. Ziegler, J. Autschbach, A. Bérces, F. M. Bickelhaupt, C. Bo, P. M. Boerrigter, L. Cavallo, D. P. Chong, L. Deng, R. M. Dickson, D. E. Ellis, M. van Faassen, L. Fan, T. H. Fischer, C. Fonseca Guerra, A. Ghysels, A. Giammona, S. J. A. van Gisbergen, A. W. Götz, J. A. Groeneveld, O. V. Gritsenko, M. Grüning, S. Gusarov, F. E. Harris, P. van den Hoek, C. R. Jacob, H. Jacobsen, L. Jensen, J. W. Kaminski, G. van Kessel, F. Kootstra, A. Kovalenko, M. V. Krykunov, E. van Lenthe, D. A. McCormack, A. Michalak, M. Mitoraj, J. Neugebauer, V. P. Nicu, L. Noodleman, V. P. Osinga, S. Patchkovskii, P. H. T. Philipsen, D. Post, C. C. Pye,
W. Ravenek, J. I. Rodríguez, P. Ros, P. R. T. Schipper, G. Schreckenbach, J. S. Seldenthuis, M. Seth, J. G. Snijders, M. Swart, D. Swerhone, G. te Velde, P. Vernooijs, L. Versluis, L. Visscher, O. Visser, F. Wang, T. A. Wesolowski, E. M. van Wezenbeek, G. Wiesenekker, S. K. Wolff, T. K. Woo and A. L. Yakovlev, ADF2010; SCM, Theoretical Chemistry, Vrije Universiteit, Amsterdam, The Netherlands; see http://www. scm.com.

32 M. J. Frisch, G. W. Trucks, H. B. Schlegel, G. E. Scuseria, M. A. Robb, J. R. Cheeseman, G. Scalmani, V. Barone, B. Mennucci, G. A. Petersson, H. Nakatsuji, M. Caricato, X. Li, H. P. Hratchian, A. F. Izmaylov, J. Bloino, G. Zheng, J. L. Sonnenberg, M. Hada, M. Ehara, K. Toyota, R. Fukuda, J. Hasegawa, M. Ishida, T. Nakajima, Y. Honda, O. Kitao, H. Nakai, T. Vreven, J. A. Montgomery, Jr., J. E. Peralta, F. Ogliaro, M. Bearpark, J. J. Heyd, E. Brothers, K. N. Kudin, V. N. Staroverov, T. Keith, R. Kobayashi, J. Normand, K. Raghavachari, A. Rendell, J. C. Burant, S. S. Iyengar, J. Tomasi, M. Cossi, N. Rega, J. M. Millam, M. Klene, J. E. Knox, J. B. Cross, V. Bakken, C. Adamo, J. Jaramillo, R. Gomperts, R. E. Stratmann, O. Yazyev, A. J. Austin, R. Cammi, C. Pomelli, J. W. Ochterski, R. L. Martin, K. Morokuma, V. G. Zakrzewski, G. A. Voth, P. Salvador, J. J. Dannenberg, S. Dapprich, A. D. Daniels, O. Farkas, J. B. Foresman, J. V. Ortiz, J. Cioslowski, D. J. Fox, Gaussian 09, Revision B.01, Gaussian, Inc., Wallingford, CT, 2010. 